\title{
The Relationship Between Parenting and Delinquency: A Meta-analysis
}

\author{
Machteld Hoeve • Judith Semon Dubas • \\ Veroni I. Eichelsheim • Peter H. van der Laan • \\ Wilma Smeenk • Jan R. M. Gerris
}

Published online: 5 March 2009

(C) The Author(s) 2009. This article is published with open access at Springerlink.com

\begin{abstract}
This meta-analysis of 161 published and unpublished manuscripts was conducted to determine whether the association between parenting and delinquency exists and what the magnitude of this linkage is. The strongest links were found for parental monitoring, psychological control, and negative aspects of support such as rejection and hostility, accounting for up to $11 \%$ of the variance in delinquency. Several effect sizes were moderated by parent and child gender, child age, informant on parenting, and delinquency type, indicating that some parenting behaviors are more important for particular contexts or subsamples.
\end{abstract}

M. Hoeve • V. I. Eichelsheim - P. H. van der Laan · W. Smeenk The Netherlands Institute for the Study of Crime and Law Enforcement (NSCR),

Amsterdam, The Netherlands

M. Hoeve $(\bowtie) \cdot$ P. H. van der Laan

Department of Educational Sciences, University of Amsterdam, P.O. Box 94208, 1090 GE Amsterdam, The Netherlands

e-mail: m.hoeve@uva.nl

J. S. Dubas

Department of Developmental Psychology,

Utrecht University,

Utrecht, The Netherlands

V. I. Eichelsheim

Department of Pedagogical and Educational Sciences,

Utrecht University,

Utrecht, The Netherlands

W. Smeenk

Research and Documentation Center of the Ministry of Justice, The Hague, The Netherlands

J. R. M. Gerris

Institute of Family and Child Care Studies,

Radboud University Nijmegen,

Nijmegen, The Netherlands
Although both dimensions of warmth and support seem to be important, surprisingly very few studies focused on parenting styles. Furthermore, fewer than $20 \%$ of the studies focused on parenting behavior of fathers, despite the fact that the effect of poor support by fathers was larger than poor maternal support, particularly for sons. Implications for theory and parenting are discussed.

Keywords Child-rearing · Delinquency · Meta-analysis . Moderators $\cdot$ Development

Parents of young people are often blamed for the delinquent behavior of their children. In some courts parents are even penalized for the antisocial conduct of their children (e.g., Bessant and Hil 1998; Drakeford 1996; Dundes 1994). Although lay as well as scholarly theories assume that a link between parenting and delinquency exists, clear conclusions concerning the magnitude of this link are difficult to draw. An important reason for this difficulty is the heterogeneity of the studies and their findings in this field of research. Studies vary on the kinds of delinquency and parenting dimensions that are investigated, on how these constructs are measured, and on the populations from which the samples are drawn. In a series of meta-analyses we summarize and integrate previous findings on the link between parenting and delinquency. The first goal is to analyze which parenting dimensions are related to delinquency and the second is to identify moderators that affect the parenting-delinquency association.

Research on family antecedents and correlates of delinquency is of direct importance to both theory and practice. Interest in the family was apparent in early theories on social disorganization (Gove and Crutchfield 1982; Van Voorhis et al. 1988), and in the social bond model of Hirschi (1969). Other theories such as those of 
Moffitt (1993, 2006) and Patterson (e.g., Patterson and Yoerger 2002) go beyond explaining only level differences in delinquency and examine how delinquency changes by age. The child's difficult behavior affects parents' disciplinary strategies, resulting in harsher and inconsistent punishments and less involvement by parents in the socialization process (Patterson 1982). These negative child-parent transactions increase the risk of setting a child off on a delinquent path that starts in the early teens, entails many delinquent acts and persists far into adulthood (Moffitt 1993; Patterson and Yoerger 2002).

Moreover, insight in these processes is essential for the development or improvement of prevention and intervention strategies. Interventions need to be "theory-driven" and based on sound research in order to be successful (Kazdin 2001). Therefore, knowledge on the link between parenting and delinquency has implications for prevention and intervention policies focusing on delinquency, in particular parent education and skills training.

\section{Conceptual Framework}

Two perspectives have been adopted in the parenting literature: research that is focused on dimensions of parenting and research focusing on typologies (Darling and Steinberg 1993; O’Connor 2002; Ten Haaf 1993). Dimensions are concepts to categorize parenting behaviors such as affection, punishment, monitoring, whereas typologies are constellations of parenting dimensions such as an authoritative parenting style which is a combination of supportive parenting, attachment and guiding the child's behavior by explanation and appropriate expectations for conformity.

Although various parenting dimensions have been proposed (see for an overview Holden 1997), two key dimensions, support and control, have been used to assess the quality of parenting behavior (Maccoby and Martin 1983). The support dimension (also labeled warmth, responsiveness or acceptance-rejection by some scholars), refers to parental behaviors toward the child that makes the child feel comfortable, accepted and approved (Rollins and Thomas 1979). The support dimension can be represented as a range of positive and negative behavioral aspects such as acceptance, affection, love, support, warmth, responsiveness, sensitivity, communication and intimacy, but also hostility, neglect, and rejection (Rohner 2004; Rollins and Thomas 1979; Ten Haaf 1993). These various aspects of parental support, whether negative or positive can be placed along the continuum of low to high support and is generally considered to be unidimenstional (Ten Haaf et al. 1994). For example, rejection is represented by low scores and acceptance by high scores. In general, supportive parenting behaviors are negatively linked to delinquency, indicating that high levels of support and warmth are associated with low levels of delinquency and that low levels of support or even rejection are linked to high levels of delinquency (e.g., Barnes and Farrell 1992; Juang and Silbereisen 1999; Simons et al. 1989).

The control dimension (also labeled demandingness), has been defined as placing demands on and controlling the child. Some scholars have argued that control should not be viewed as unidimensional, since this dimension could be further divided into separate constructs with different meanings. A common approach is to distinguish between authoritative control and authoritarian control (Baumrind 1968, 1971). Authoritative control reflects child-oriented and inductive discipline techniques such as guiding the child's behavior cognitively, giving information, and stimulating responsible behavior of the child, while authoritarian control refers to adult-oriented, coercive, restrictive, and firm discipline techniques and emphasizes the negative aspects of control such as harsh punishment and love withdrawal (e.g., Baumrind 1968, 1971). In general, authoritative control has positive effects on child behavior, while authoritarian control has been found to have negative effects on the child (Baumrind 1966). Too strict authoritarian control (Farrington 1989) and harsh punishment (Farrington et al. 2003) appear to be linked to high levels of delinquent and antisocial behavior, although effect sizes vary substantially across studies (Loeber and Stouthamer-Loeber 1986).

More recently, Barber and colleagues have argued for a focus on behavioral and psychological control instead of authoritative and authoritarian control (e.g., Barber 1996; Barber et al. 2005). Behavioral control is defined as parents' attempts to control and regulate their children's behavior by rules setting and monitoring. Aspects of behavioral control such as monitoring (Fischer 1983) and consistency in discipline (Coughlin and Vuchinich 1996) have been associated with low levels of delinquency (see also Patterson 1982). Psychological control refers to intrusions into the psychological development of the child, such as love withdrawal, keeping the child dependent and the use of guilt to control the child. Behavioral control is more strongly linked to externalizing problems in adolescents, while psychological control is more strongly associated with internalizing problems (Barber et al. 1994). Thus, the parenting dimension control is often seen as a multidimensional concept. In the present analysis, this dimension is separated into either authoritative control and authoritarian control or behavioral control and psychological control.

Besides parenting dimensions, parenting typologies or styles are examined. Elaborating on the work of Baumrind (1966, 1971), Maccoby and Martin (1983) defined parenting 
styles according to a two-dimensional framework of support and control. Accordingly, four parenting styles can be identified: authoritarian (low support, high control), authoritative (high support and control), permissive (high support and low control), and neglecting (low support and control). Parenting styles are configurations of attitudes and behaviors of parents towards their child and create a context or a climate for the parent's behavior and is displayed across many different situations (Darling and Steinberg 1993). From a typological viewpoint single parenting behaviors do not properly account for the interactional nature and dynamics of families and therefore parenting dimensions should not be examined in isolation (O'Connor 2002). Prior research revealed that an authoritative style had positive effects on child adaptation, whereas the remaining styles place the child at risk for negative child outcomes (Maccoby and Martin 1983). Neglectful parenting in particular has been linked to delinquent behavior (Maccoby and Martin 1983; Steinberg et al. 2006; Steinberg et al. 1994).

In the present study we examine various parenting dimensions, including parental support, and various types of control, and patterns of parenting behaviors (i.e., parenting styles) in relation to delinquency. We also examine discrete parenting behaviors (such as affection, hostility, monitoring, etc.) in order to identify which specific child-rearing characteristics are linked to child outcomes with the purpose of discovering effective ingredients for interventions.

\section{Prior Meta-analyses}

There are several reasons that make it appropriate to conduct a meta-analysis. First, a considerable body of empirical research on the relationship between family factors and delinquency exists. Moreover, the inconsistencies in the literature make it difficult to summarize the results in a narrative review. For example, Wells and Rankin (1988) concluded that aspects of parental control such as normative regulation, monitoring and punishment have the same impact on delinquency as parental attachment, whereas Wright et al. (2000) concluded that results on parental control are mixed with inconsistent findings. A meta-analysis is useful for identifying whether effect sizes are homogeneous across studies and in the case where they are not, moderators can be investigated to identify the source of the mixed results.

A few meta-analyses have examined the association between parenting and delinquency. Several meta-analyses focused on risk factors for delinquency have included family factors (Cottle et al. 2001; Gendreau et al. 1996; Hubbard and Pratt 2002; Lipsey and Derzon 1998; Loeber and Dishion 1983). Next to offence history, family factors were among the best predictors of recidivism compared to other domains, such as socio-economic status, intellectual functioning, and personal distress (Cottle et al. 2001; Gendreau et al. 1996). A disadvantage of meta-analyses on risk factors is that the units of focus are very broad and several family factors such as family size, attachment, and punishment have been combined into the same category. Furthermore, only a small number of parenting characteristics have been included in these reviews.

Only one previous meta-analysis considered the association between various aspects of parenting and delinquency (Loeber and Stouthamer-Loeber 1986) and included such factors as neglect (e.g., parent-child involvement), conflict (discipline and rejection), deviant behaviors and attitudes (e.g., parental criminality), and disruption (e.g., marital relations and parental absence). Among the over seventy studies reviewed, the best predictors of delinquency and problem behavior included lack of parental supervision, parental rejection, and parent-child involvement. Parental discipline appeared to be a weaker predictor than other family variables.

The present study extends the work of Loeber and Stouthamer-Loeber (1986) by using more advanced metaanalytic techniques including tests of homogeneity of effect sizes and moderator analyses. Moreover, the present metaanalysis includes many new investigations that have been completed since the Loeber and Stouthamer-Loeber review.

\section{Moderator Analysis}

Studies differ considerably with regard to characteristics of the sample and measurement instruments, and these factors may influence the magnitude of the link between parenting and delinquency. Therefore, our second goal is to identify potential moderators. We consider four main moderators: gender of the child and the parent, delinquency source and type, informant on parenting (parent or child), and shortvs. long-term relationships and also analyze methodological moderators related to study quality.

\section{Sex-Differences}

Males are more involved in delinquent behavior than females. One of the explanations of the higher level of delinquency in males than in females is that the etiology of delinquency may differ for males and females. Males may be more vulnerable to risk factors for delinquency such as inadequate parenting than females (Moffitt et al. 2001). Another hypothesis is that risk factors for delinquency are the same for males and females (Moffitt et al. 2001) but that males are exposed to risk factors more than females. Studies on sex-differences in the link between family 
factors and delinquency are scarce and their findings are contradictory. Some studies report stronger effects of parenting variables in girls (e.g., Nye 1958), while others conclude that the family is more important to boys (Hay 2003; Rothbaum and Weisz 1994) and still others find very few sex-differences in family risk factors of delinquency (Hubbard and Pratt 2002; Loeber and Stouthamer-Loeber 1986). Therefore, studies on males and females are compared in the current meta-analysis in order to help clarify theoretical and empirical discrepancies.

In addition to child gender, the gender of the parent is also included. The link between fathers' parenting and mothers' parenting to adolescents' delinquency may differ for several reasons. First, apart from the fact that the quantity of the time fathers and mothers spend with their children is different, there are indications that parental involvement is also qualitatively different (Videon 2005). Compared to other relatives such as the mother, siblings, and grandparents, the father's arrest is the strongest predictor of the boy's offending behavior (Farrington et al. 2001). Moreover, the longer antisocial fathers live with their families the higher the risk for their children's antisocial behavior (Jaffee et al. 2003). A possible explanation for this finding is that children have the tendency to model the behavior of the parent with the same sex (Laible and Carlo 2004) and yet it is also likely that these fathers exhibit problematic parenting behaviors. Despite these results, relatively little research has examined the quality of fathers' parenting compared to mothers' parenting in relation to the child's well-being and behavior (Williams and Kelly 2005).

\section{Short-Term vs. Long-Term Associations}

Another important issue is whether or not parental behavior and parent-child relations have stronger or weaker relations to delinquency over time. The bidirectional-transactional feature of child-rearing (Colpin 1999) suggests that change is possible; nevertheless, parenting is found to be relatively stable across time (Holden and Miller 1999). Theories on the causes of crime have contradictory hypotheses on this issue. Static theories, such as Gottfredson and Hirschi's theory (1990) which focus on inter-individual differences suggest that the parenting-delinquency link is relatively the same over the life-course. This hypothesis has been challenged by dynamic developmental theories such as Sampson and Laub's (2005) age-graded theory predicting that the relationship between parenting and delinquency will change over time. As youngsters age, social ties to labor or marriage can modify trajectories of criminal offending and the influence of the family of origin should decrease over time. In light of the theories concerning whether the family has enduring importance we address this issue empirically by testing whether study design (cross-sectional or longitudinal), time-interval between measurements, and age of the subjects moderate the parenting-delinquency link.

\section{Delinquency Type and Source}

Some scholars argue that self-report measures should be used for less serious crimes and for most serious crimes one should collect information from official records (Babinski et al. 2001). One of the reasons for this is that participants are less likely to report serious stigmatizing crimes, such as assault and hitting a spouse or partner than minor delinquency (Babinski et al. 2001). Some scholars maintain that results are generally similar for studies that used selfreported delinquency compared to those examining official measures (Gove and Crutchfield 1982), while others finding stronger results for official records compared to self reports (Loeber and Stouthamer-Loeber 1986).

Related to the seriousness is the type of delinquency. Delinquency type is typically classified in two categories: overt and covert delinquency (e.g., Loeber 1996). Overt delinquency refers to violent offences such as attacking someone with or without a weapon, threatening, murder, and rape. Covert delinquency refers to non-aggressive acts such as shoplifting, pick pocketing, arson, vandalism, and selling drugs. Overt aggressive and more serious offences are more common in early-onset delinquents. These delinquents are furthermore characterized by problems in their childhood such as poor family functioning (Moffitt and Caspi 2001). Covert non-aggressive delinquency, on the other hand, is relatively more often found in nonpersistent adolescent-onset delinquents, who have relatively normal backgrounds (Moffitt and Caspi 2001). On the basis of these findings one would expect to find stronger links between poor parenting and overt delinquency compared to covert delinquency. Loeber et al. (2008) studied antecedents of violence and theft and found many unique factors that differentially predicted violence and theft, in particular at older ages. For example, engaging in a family social welfare program was predictive of violence whereas child maltreatment was predictive of theft. These findings stress the importance of distinguishing between overt and covert delinquency. Given these issues, we included the source (self-reported or official delinquency) and type (overt or covert) of delinquency as a possible moderator on the parenting-delinquency link.

\section{Parenting Informant}

Some studies on parenting and delinquency used information about parenting reported by the child, whereas other studies used the parent as an informant. Results of 
parenting-delinquency associations may be different for these informants, because family members experience their interactions differently and therefore have dissimilar views on parenting and parent-child relations (e.g., Lanz et al. 2001) with parents more likely to outline the positive characteristics of their family (Steinberg 2001) whereas adolescents tend to overestimate the negative aspects of parenting because they want to express their uniqueness and independence (Noller and Callan 1988). In the present meta-analysis, studies with the child as informants are therefore compared with studies on parenting reported by the parent.

\section{Methodological Moderators}

Following Mullen's (1989) advice to include studies of varying quality, no studies were excluded on the basis of the quality of their design. The reason for this is that assessing the quality of a study appropriately is complicated and often problematic. However, as a check on quality control, we also examined whether several methodological characteristics (sample size, number of items in delinquency and parenting questionnaires, reliability of the parenting questionnaire, publication status, and journal impact factor), moderated the link between parenting and delinquency.

In summary, this study addresses the following research questions: Which parenting dimensions, styles, and behaviors are related with delinquency? How strong is the connection between parenting and delinquency? Do stronger associations emerge with samples of males or females and with fathers or mothers? Are long-term associations stronger than short-term associations? Which source (self-reported or official) and type (overt or covert) of delinquency yields the strongest effect sizes? Which informant of parenting (parent or child) yields the strongest parenting-delinquency association? Finally, as has been done in previous meta-analyses we also examine methodological characteristics which are indicators of the study quality.

\section{Method}

Selection of the Studies

Four selection criteria were used to select studies: operationalization of delinquency and parenting (described in more detail below), investigations on Western samples only (given cultural differences in parenting), and investigations where bivariate associations between parenting and delinquency were reported (as multivariate results cannot be compared across studies). Delinquency was defined as behavior prohibited by the law were selected. ${ }^{1}$ Parenting was defined as behavior of the parent that is directed toward the child and therefore included such practices as punishment, monitoring, affection, and communication. Factors that referred to behavior of the parent in which the child was not directly involved, such as criminality by parents, marital problems, and parental depression were excluded.

On the basis of the selection criteria, studies were collected according to the following procedure. First, electronic databases such as ERIC, PsycINFO, Sociological Abstracts and Criminal Justice Abstracts were searched for articles, books, chapters, paper presentations, dissertations and reviews. Search terms such as delinquency, crime, criminals, offenders, anti-social were cross-referenced with parenting, child-rearing, and parent-influence. Next, manual searches were applied in which reference lists of reviews and other articles were checked in order to find relevant studies not found in the electronic databases. Finally, experts in the field were asked whether they knew of any other relevant published or unpublished studies. ${ }^{2}$ We found a total of 161 published and unpublished papers that met the selection criteria.

\section{File Drawer Problem}

Publication bias is the tendency of journals to accept papers that report strong significant associations over publications with nonsignificant or small effects (e.g., Mullen 1989; Rosenthal 1991). Rosenthal (1979) identified this problem as the file drawer problem. The best solution to this difficulty is to try to obtain all published and unpublished material as best as possible. Additionally, a method to test whether the results of the analysis of the combined effect sizes are reliable is to calculate a fail-safe number (Rosenthal 1991), the number of unpublished studies that have not been found with a non-significant result that will decrease the combined effect size to non-significant. The present meta-analysis includes unpublished studies and also provides fail-safe numbers. However, because the quality of unpublished studies is questioned because they have not gone through peer review, we noted and analyzed the effects of publication status (i.e., published or not) and four other quality indicators: reliability of questionnaires (0.39-0.96), sample size (35-6,751),

\footnotetext{
${ }^{1}$ Studies on problem behavior, which we consider as behavior that is not prohibited by the law, were not included. Nevertheless, we found many studies that used self-reported questionnaires for measuring delinquency. Often, these questionnaires had both items on problem behavior or status offences and delinquency. These studies were included in our meta-analysis.

${ }^{2}$ We contacted Rolf Loeber, Magda Stouthamer-Loeber, and Maja Dekovic, who drew our attention to four other empirical studies that we did not detect through the other methods.
} 
number of informants (1-5), and impact factor of the publication (0.157-10.519). Impact factor refers to the average number of citations to the articles in a journal. We assigned an impact factor of zero if studies were presented in paper presentations, dissertations, books, and book chapters.

\section{Classification of Parenting Variables}

In total 432 different parenting variables were identified across the 161 studies. The parenting variables were classified into nine constructs or categories which were made on the basis of the literature on parenting. Parenting behaviors (behaviors of parents directed to the child) were assigned to the parenting dimensions: (1) support, (2) authoritative control, (3) authoritarian control, (4) behavioral control -including active monitoring ${ }^{3}$, (5) psychological control, (6) general control-concepts that are too broad for classification in a specific kind of control, (7) general parenting - aspects that covered both support and control, (8) indirect parenting behaviorparental knowledge and child disclosure (see footnote 3), and (9) other parenting - all remaining parenting that did not fit the other categories (e.g., fairness of discipline, coparenting). Given that the variables in the last category do not conceptually form a unity, we only described the results of these studies and computed mean effect sizes for each parenting behavior in this category if there are at least three studies. We did not subject this category to moderator analyses. The classification system including a list of the parenting categories and variables is presented in the Appendix. The first author coded the parenting variables on the basis of their names and descriptions. Reliability of the coding scheme was checked by having 100 randomly selected parenting variables coded by two educational sciences students. After training, the students independently classified the parenting variables into the categories. Interrater agreement was quite high with the percentage of agreement between the first author and the students being $87.0 \%$ and $87.1 \%(\kappa=0.85$ vs. $\kappa=0.85)$ and $88.6 \%(\kappa=0.87)$ between the two students.

\section{Coding of Moderator Variables}

Study characteristics were extracted from the articles and reports (see Table 1 for an overview). The following study

\footnotetext{
$\overline{3}$ Parental monitoring is often operationalized as parental knowledge of the child's whereabouts, while this is not parental behavior (e.g., Kerr et al. 1999). Therefore we distinguished between active monitoring behavior by the parent, parental knowledge, and information on whereabouts given by the child. Parental monitoring was classified into the category behavioral control and parental knowledge and child disclosure were classified into the category indirect parenting behavior.
}

Table 1 Description of Some Major Characteristics of Article and Study Used in the Present Meta-Analysis

\begin{tabular}{|c|c|c|}
\hline Study characteristics & Frequency & Percentage \\
\hline \multicolumn{3}{|l|}{ General study characteristics } \\
\hline \multicolumn{3}{|l|}{ Year of publication $(k=161)$} \\
\hline 1950-1970 & 9 & 5.6 \\
\hline 1970-1979 & 6 & 3.7 \\
\hline 1980-1989 & 20 & 12.4 \\
\hline 1990-1999 & 57 & 35.4 \\
\hline $2000-2007$ & 69 & 42.9 \\
\hline \multicolumn{3}{|l|}{ Publication status $(k=161)$} \\
\hline Published & 143 & 88.8 \\
\hline Unpublished & 18 & 11.2 \\
\hline \multicolumn{3}{|l|}{ Impact factor ${ }^{\mathrm{a}}(k=161)$} \\
\hline 0 & 42 & 26.1 \\
\hline 0.163 to 0.999 & 40 & 24.8 \\
\hline 1 to 1.999 & 23 & 14.3 \\
\hline 2 to 2.999 & 1 & 0.6 \\
\hline 3 to 3.999 & 23 & 14.3 \\
\hline 4 to 4.999 & 12 & 7.5 \\
\hline 10 to 13.936 & 1 & 0.6 \\
\hline Not specified & 19 & 11.8 \\
\hline \multicolumn{3}{|l|}{ Sample characteristics } \\
\hline \multicolumn{3}{|l|}{ Continent $(k=119)$} \\
\hline North America & 83 & 69.7 \\
\hline Europe & 32 & 26.9 \\
\hline Australia & 4 & 3.4 \\
\hline \multicolumn{3}{|l|}{ Degree of urbanization $(k=119)$} \\
\hline Urban area & 69 & 58.0 \\
\hline Rural area & 8 & 6.7 \\
\hline Mixed & 32 & 26.9 \\
\hline Not specified & 10 & 8.4 \\
\hline \multicolumn{3}{|l|}{ Sample type $(k=126)$} \\
\hline Delinquents overrepresented & 42 & 33.3 \\
\hline Representative & 70 & 55.6 \\
\hline Other & 14 & 11.1 \\
\hline \multicolumn{3}{|l|}{ Sex of the target child $(k=149)$} \\
\hline Males & 43 & 29.5 \\
\hline Females & 24 & 16.4 \\
\hline Mixed & 79 & 54.1 \\
\hline \multicolumn{3}{|c|}{ Percentage of ethnic minorities $(k=130)$} \\
\hline $0-10$ & 32 & 24.6 \\
\hline $10-19$ & 13 & 10.0 \\
\hline $20-29$ & 4 & 3.1 \\
\hline $30-39$ & 8 & 6.2 \\
\hline $40-49$ & 9 & 6.9 \\
\hline $50-59$ & 4 & 3.1 \\
\hline $60-69$ & 0 & 0.0 \\
\hline $70-79$ & 2 & 1.5 \\
\hline $80-89$ & 5 & 3.8 \\
\hline $90-100$ & 19 & 14.6 \\
\hline
\end{tabular}


Table 1 (continued)

\begin{tabular}{|c|c|}
\hline Study characteristics & Freque \\
\hline Not specified & 34 \\
\hline \multicolumn{2}{|c|}{ Delinquency characteristics } \\
\hline \multicolumn{2}{|c|}{ Delinquency type $(k=133)$} \\
\hline General delinquency & 106 \\
\hline Overt delinquency & 17 \\
\hline Covert delinquency & 10 \\
\hline \multicolumn{2}{|c|}{ Source of delinquency $(k=132)$} \\
\hline Self-report & 100 \\
\hline Official record & 20 \\
\hline Combination & 9 \\
\hline Parent report & 3 \\
\hline \multicolumn{2}{|c|}{ Number of informants $(k=127)$} \\
\hline 1 & 116 \\
\hline 2 & 7 \\
\hline 3 & 3 \\
\hline 4 & 1 \\
\hline \multicolumn{2}{|l|}{ Age $(k=160)$} \\
\hline $6.0-8.9$ & 2 \\
\hline $9.0-11.9$ & 9 \\
\hline $12.0-14.9$ & 47 \\
\hline $15.0-17.9$ & 72 \\
\hline $18.0-20.9$ & 12 \\
\hline $21.0-29.9$ & 8 \\
\hline $30.0-59.9$ & 8 \\
\hline Not specified & 2 \\
\hline Age range $(k=129)$ & \\
\hline
\end{tabular}

2-5 58

$6-10 \quad 42$

11-18

Not specified

Period $^{\mathrm{b}}(k=147)$

0 to -1

-1 to -3

-3 to -10

$<-10$

Ever

Incarcerated

Not specified

Percentage of problem behavior $(k=13$

$0 \%$

$1-19.99 \%$

20-39.99\%

40-59.99\%

60-79.99\%

Not specified

Parenting characteristics

Actor $(k=293)$

Father
Table 1 (continued)

\begin{tabular}{|c|c|c|}
\hline Study characteristics & Frequency & Percentage \\
\hline Mother & 65 & 22.2 \\
\hline $\begin{array}{l}\text { Both parents or parent } \\
\text { not specified }\end{array}$ & 170 & 58.0 \\
\hline \multicolumn{3}{|l|}{ Informant $(k=293)$} \\
\hline Parent & 47 & 16.0 \\
\hline Subject & 202 & 68.9 \\
\hline Observer & 9 & 3.1 \\
\hline Official record & 1 & 0.3 \\
\hline Combination & 34 & 11.6 \\
\hline \multicolumn{3}{|c|}{ Number of informants $(k=293)$} \\
\hline 1 & 259 & 88.4 \\
\hline 2 & 16 & 5.5 \\
\hline 3 & 12 & 4.1 \\
\hline 4 & 1 & 0.3 \\
\hline 5 & 5 & 1.7 \\
\hline \multicolumn{3}{|l|}{$\operatorname{Age}^{\mathrm{c}}(k=293)$} \\
\hline $5-7.9$ & 3 & 1.0 \\
\hline $8-10.9$ & 27 & 9.2 \\
\hline $11-13.9$ & 73 & 24.9 \\
\hline $14-16.9$ & 153 & 52.2 \\
\hline $17-19.9$ & 23 & 7.8 \\
\hline $20-39.9$ & 7 & 2.4 \\
\hline Not specified & 7 & 2.4 \\
\hline \multicolumn{3}{|l|}{ Age range $(k=293)$} \\
\hline 1 year & 45 & 15.4 \\
\hline $2-5$ & 144 & 49.1 \\
\hline $6-10$ & 88 & 30.0 \\
\hline $11-18$ & 7 & 2.4 \\
\hline Not specified & 9 & 3.1 \\
\hline \multicolumn{3}{|c|}{ Methodological characteristics } \\
\hline \multicolumn{3}{|c|}{ Sample size $(k=293)$} \\
\hline $34-50$ & 8 & 2.7 \\
\hline $50-99$ & 31 & 10.6 \\
\hline $100-199$ & 42 & 14.3 \\
\hline $200-499$ & 102 & 34.8 \\
\hline $500-999$ & 60 & 20.5 \\
\hline $1,000-9,999$ & 50 & 17.1 \\
\hline \multicolumn{3}{|l|}{ Time interval $(k=293)$} \\
\hline 0 years & 208 & 71.0 \\
\hline $0.1-4.9$ & 47 & 16.0 \\
\hline $5-9.9$ & 16 & 5.5 \\
\hline $10-35$ & 22 & 7.5 \\
\hline \multicolumn{3}{|l|}{ Test statistic $(k=293)$} \\
\hline Continuous & 233 & 79.5 \\
\hline Dichotomous & 42 & 14.3 \\
\hline Mixed & 13 & 4.4 \\
\hline Other & 5 & 1.7 \\
\hline \multicolumn{3}{|l|}{ Design $(k=127)$} \\
\hline Cross-sectional & 88 & 69.3 \\
\hline
\end{tabular}


Table 1 (continued)

\begin{tabular}{|c|c|c|}
\hline Study characteristics & Frequency & Percentage \\
\hline Longitudinal & 35 & 27.6 \\
\hline Retrospectief & 4 & 3.1 \\
\hline \multicolumn{3}{|c|}{ Number of items (delinquency; $k=149$ ) } \\
\hline 1 & 3 & 2.0 \\
\hline 2 to 5 & 10 & 6.7 \\
\hline 6 to 10 & 31 & 20.8 \\
\hline 11 to 20 & 41 & 27.5 \\
\hline 21 to 50 & 31 & 20.8 \\
\hline 51 to 100 & 4 & 2.7 \\
\hline 101 to 130 & 1 & 0.7 \\
\hline Not specified & 28 & 18.8 \\
\hline \multicolumn{3}{|c|}{ Number of items (parenting variables; $k=293$ ) } \\
\hline 1 & 31 & 10.6 \\
\hline 2 to 5 & 76 & 25.9 \\
\hline 6 to 10 & 81 & 27.6 \\
\hline 11 to 20 & 28 & 9.6 \\
\hline 21 to 30 & 8 & 2.7 \\
\hline 31 to 40 & 10 & 3.4 \\
\hline 41 to 50 & 2 & 0.7 \\
\hline 51 to 60 & 2 & 0.7 \\
\hline Not specified & 55 & 18.8 \\
\hline \multicolumn{3}{|c|}{ Reliability (parenting variables; $k=293$ ) } \\
\hline 0.39 to 0.50 & 4 & 1.4 \\
\hline 0.51 to 0.60 & 10 & 3.4 \\
\hline 0.61 to 0.70 & 32 & 10.9 \\
\hline 0.71 to 0.80 & 63 & 21.5 \\
\hline 0.81 to 0.90 & 71 & 24.2 \\
\hline 0.91 to 0.96 & 8 & 2.7 \\
\hline Not specified & 105 & 35.8 \\
\hline
\end{tabular}

For the General study characteristics $k$ equals the number of articles. For the sample characteristics, $k$ equals the number of samples; for the parenting characteristics, $k$ equals the number of analyses

${ }^{a}$ Impact factors were retrieved from ISI Web of Knowledge. Journals not found in this database fall under 'Not specified'

${ }^{b}$ The period in which delinquent behavior took place, for example -1 means that crimes were committed in the last year, and -3 means that crimes were committed in the last 3 years

${ }^{\mathrm{c}}$ Age at the time of the parenting measurement goes past 18 years, because several studies had a retrospective design

characteristics were analyzed as moderators. In order to analyze sex-differences we coded sex of the target child (males, females, or both) and the active agent or actor (e.g., father, mother, both parents or parents not specified). With regard to short-term versus long-term associations we coded: design (cross-sectional, longitudinal, or retrospective), time interval in months between the two measurements (if the study design was cross-sectional this variable was set at zero), age of the subjects at the time of the delinquency measurement, and age of the subjects at the time of measurement of the parenting characteristic. With regard to delinquency type and source we coded: delinquency type (general delinquency, overt delinquency, or covert delinquency), percentage of problem behavior within the delinquency construct (i.e., the proportion of items on non-illegal problem behavior within questionnaires on delinquency), and source of delinquency information (selfreport, official record, or both). Furthermore, we coded the informant of the parenting characteristic (e.g., father, mother, subject, observer). Finally, the following methodological characteristics were coded: publication status (published, unpublished), impact factor of the journal (zero for unpublished studies and book chapters), sample size, number of items in delinquency self-report questionnaire, number of items in parenting questionnaire, reliability of parenting questionnaire (Cronbach's alpha).

Analyses

For each study an effect size was calculated. We used Pearson's $r$ to express the relationship between a parenting characteristic and delinquency. We used the formulas of Mullen (1989) to transform the test statistics $\chi^{2}, F, t$ or $p$ values into correlation $r$. The test statistic $\phi$ (phi) was transformed to a $\chi^{2}$ via the formula $\chi^{2}=\varphi^{2} \times N$, with $N$ as the sample size which in turn was transformed to $r$. When studies reported odds ratio's and $\gamma$ 's, we constructed a $2 \times 2$ cross-table in order to calculate a $\chi^{2}$, using information about percentages of delinquent behavior and parenting variables. If these proportions were not presented, we applied the approximation of a tetrachoric correlation of Digby to transform the odds ratio's into correlations (Bonett 2007). If studies only reported that a relationship was significant or not, we applied conservative estimation procedures, meaning that we assigned a $p$ value of 0.50 if a non-significant effect was reported and a $p$ value of 0.05 for significant associations (Mullen 1989).

Each correlation $r$ was transformed to a Fisher's $Z$ before combined effect sizes were calculated and moderatoranalyses were conducted (Mullen 1989). For each parenting category we conducted a meta-analysis. We examined the extent of the variation in effect sizes (Hedges and Olkin 1985). For the calculation of combined effect sizes and the moderator-analyses, we used the SPSS macros of Lipsey and Wilson (2001) and random effects models given that most effect sizes were heterogeneous (Lipsey and Wilson 2001; Rosenthal 1995). This method is rather conservative and has the advantage of allowing the results to generalize to studies that are not in the meta-analysis. Furthermore, we calculated fail-safe numbers and analyzed whether outlying effect sizes were in our data base of studies on the basis of standardized $z$-values larger than 3.29 or smaller than -3.29 (Tabachnick and Fidell 1989). No outliers were identified. 
Independence of Study Results

Independence of study results is desirable when conducting a meta-analysis in order to preclude that a particular study is weighted more strongly than the others (Lipsey and Wilson 2001). In the current meta-analysis, dependence of study results was prevented by combining the results of dependent studies or by using only one study result. We used three different methods for eliminating dependence. First, in some manuscripts results regarding the same sample were reported and therefore the results across studies were combined into one effect size and used that in all sub-analyses. For example, results on the relationship between monitoring and delinquency in the CambridgeSomerville Youth Study were published in three journal articles (McCord 1991a, b, 1996).

Second, if a study characteristic of a dependent study was less common, we used only this study result. For example, both self-reported delinquency and official delinquency were analyzed regarding the same sample (Farrington 1989, 1990, 2002; Farrington and Hawkins 1991; Farrington and Loeber 1999; West and Farrington 1973, 1977). We chose the analyses on official delinquency, because studies on official delinquency are less commonly available. If a study reported results for both males and females, we used the results on females (e.g., Riley and Shaw 1985). In some other studies both the mother and father were informants on their parenting behavior. Given that studies on fathers' parenting behavior were relatively scarce, we selected studies on fathers (e.g., Stattin and Kerr 2000).

Third, some manuscripts reported on more than one sample (e.g., Heaven and Virgen 2001). In most cases we averaged the results following the procedure of Mullen (1989). To retain the distinctions between the discrete parenting behaviors in the analyses, rather than averaging the results or selecting one of them, we used Cooper's (1989) shifting unit of analysis. For the analysis on the level of the discrete parenting behaviors we used all analyses within one study. However, in analyses at the level of parenting dimensions we selected one analysis per study.

\section{Results}

\section{Description of Studies}

Table 1 presents a description of the 161 manuscripts, containing 119 independent studies. As shown in the table, the majority of the data came from studies conducted in the United States. All studies that we included in the metaanalysis were published between 1950 and 2007. The majority of studies (87\%) was conducted after 1986, the year in which the meta-analysis of Loeber and Stouthamer-Loeber (1986) was published. The sample sizes were quite varied, ranging from 34 to 18,260 , with most between 200 and 500. The designs were most frequently cross-sectional (88 studies). Only four studies used a retrospective design, and 35 studies were longitudinal. The data included samples of only females, only males or both. Samples with only females were relatively limited (16\%). Furthermore, the vast majority of samples consisted of a certain proportion of ethnic minorities $(85 \%)$.

\section{Central Tendency}

Parenting Dimensions Mean effect sizes for associations between parenting dimensions (support and various forms of control) and delinquency were all significant and ranged in strength from.12 for authoritative and authoritarian control to 0.23 for psychological control (Table 2). Differences in mean effect sizes between parenting dimensions were significant $(Q(5)=13.7, p<0.05)$. Among the parenting dimensions the highest mean effect sizes were found for psychological control, referring to parents who keep their child dependent, try to change the feelings of their child, use guilt to control the child or ignore the child as a form of punishment. Furthermore, general control, referring to variables that combine various aspects of discipline into one construct, was significantly related to delinquency and had a relatively high effect size $(\mathrm{ES} r=-0.21)$. According to the criteria of Cohen (1988) for small, moderate and large effect sizes ( $r=0.10, r=0.24$, and $r=0.37$ respectively), the correlation between psychological control and general control, and delinquency are moderate in size. The remaining parenting dimensions, support, and authoritative, authoritarian and behavioral control, have small to moderate significant associations with delinquency. Post-hoc comparisons revealed that differences between the four types of control were significant $(Q(3)=8.8, p<0.05)$ and that differences in effect sizes between support and control dimensions and between behavioral and psychological control were nonsignificant $(Q(1)=0.03, p>0.10$ for support versus control; $Q(1)=1.0, p>0.10$ for behavioral vs. psychological control).

Given that scholars consider the support dimension as unidimensional (e.g., Ten Haaf et al. 1994), we initially did not further divide the support dimension into separate constructs with different meanings. However, we hypothesized that low levels of positive aspects of support might result in different mean effect sizes than high levels of negative aspects of support. For example, high levels of hostility and neglect may be more harmful for youngsters than low levels of understanding and support. In order to test 
Table 2 Meta-analytic Results For Each Parenting Category
$\mathrm{ES} r$ refers to the mean effect size and can be interpreted as a correlation $r$. Class between parentheses refers to a set of more than one aspect of this category (see Appendix). $Q=$ within-class homogeneity statistic

${ }^{*} p<0.10, * * p<0.05$,

$* * * p<0.01, * * * * p<0.001$

\begin{tabular}{|c|c|c|c|c|}
\hline Category & Studies $(k)$ & Subjects $(N)$ & Effect size $(\mathrm{ES} r)$ & $Q$ \\
\hline Support & 72 & 46,960 & $-0.19 * *$ & $877.02 * * * *$ \\
\hline Affection & 12 & 3,901 & $-0.21 * * * *$ & $46.8 * * * *$ \\
\hline Involvement & 3 & 861 & $-0.16^{*}$ & $16.9 * * * *$ \\
\hline Supportive parenting & 5 & 3,983 & $-0.23 * * * *$ & $8.9^{*}$ \\
\hline Open communication & 11 & 7,959 & $-0.07 *$ & $76.1 * * * *$ \\
\hline Support positive (class) & 29 & 24,268 & $-0.19 * * * *$ & $538.0 * * * *$ \\
\hline Neglectful & 3 & 540 & $0.29 * * *$ & 1.8 \\
\hline Rejection & 6 & 1,589 & $0.26^{* * * *}$ & $16.1 * * *$ \\
\hline Hostility & 5 & 1,252 & $0.28 * * * *$ & 7.3 \\
\hline Support negative (class) & 3 & 1,323 & $0.33 * * * *$ & $29.7 * * * *$ \\
\hline Authoritative control & 15 & 9,162 & $-0.12 * *$ & $45.71 * * * *$ \\
\hline Rewarding & 7 & 3,976 & $-0.11 * * *$ & $30.6 * * * *$ \\
\hline Inductive parenting & 5 & 1,071 & $-0.13 * * *$ & 6.9 \\
\hline Authoritative control (class) & 4 & 3,944 & $-0.11 * *$ & $8.0 * *$ \\
\hline Authoritarian control & 38 & 21,365 & $0.12 * *$ & $250.22 * * * *$ \\
\hline Physical punishment & 12 & 8,089 & $0.10 * * *$ & $125.2 * * * *$ \\
\hline Verbal aggression as punishment & 3 & 1,400 & $0.14 * *$ & 1.5 \\
\hline Punishment & 10 & 2,704 & $0.13 * * *$ & $46.7 * * * *$ \\
\hline Authoritarian control (class) & 24 & 15,422 & $0.16^{* *}$ & $123.9^{* * * *}$ \\
\hline Behavioral control & 55 & 40,378 & $-0.19 * *$ & $1055.85 * * * *$ \\
\hline Consistent discipline & 5 & 2,255 & -0.12 & $14.4^{* *}$ \\
\hline Inconsistent discipline & 4 & 3,139 & $0.20 * * *$ & $19.0 * * * *$ \\
\hline Discipline & 6 & 1,691 & $-0.20 * * *$ & $33.4 * * * *$ \\
\hline Rules setting & 8 & 9,887 & $-0.13 * * *$ & 7.2 \\
\hline Decision making & 3 & 3,245 & $-0.18^{* *}$ & 2.1 \\
\hline Permissiveness & 10 & 10,391 & $0.09 * *$ & $95.5^{* * * *}$ \\
\hline Monitoring & 28 & 19,289 & $-0.23 * * * *$ & $541.5 * * * *$ \\
\hline Behavioral control (class) & 22 & 16,126 & $-0.16^{* * * *}$ & $195.4 * * * *$ \\
\hline Psychological control & 23 & 10,344 & $0.23 * *$ & $189.37 * * *$ \\
\hline Psychological control & 13 & 5,190 & $0.21 * * * *$ & $52.4 * * * *$ \\
\hline Overprotection & 3 & 3,426 & $0.21 * * * *$ & $61.2 * * * *$ \\
\hline Psychological control (class) & 10 & 3,165 & $0.23 * * * *$ & 10.6 \\
\hline General control & 11 & 4,187 & $-0.21 * *$ & $57.64 * * * *$ \\
\hline General parenting & 17 & 21,405 & $-0.17 * *$ & $105.85^{* * * *}$ \\
\hline Parenting & 16 & 18,937 & $-0.18 * * * *$ & $103.0 * * * *$ \\
\hline Authoritative parenting style & 8 & 9,089 & $-0.19 * * * *$ & $26.9 * * * *$ \\
\hline Indirect parenting behavior & 51 & 36,121 & $-0.26 * *$ & $762.16 * * * *$ \\
\hline Knowledge & 47 & 32,847 & $-0.26^{* * * *}$ & $742.1 * * * *$ \\
\hline Child disclosure & 11 & 6,965 & $-0.31 * * * *$ & $114.8 * * * *$ \\
\hline \multicolumn{5}{|l|}{ Other parenting } \\
\hline Co-parenting & 4 & 1,200 & $-0.13^{* * * *}$ & 2.5 \\
\hline
\end{tabular}

this hypothesis we compared the effect sizes of negative versus positive aspects of support. Parenting behaviors such as trust, acceptance, supportive parenting, open communication, love, caring and warmth were considered as positive aspects of support (47 studies) and indifference, avoidance, neglect, hostility and rejection were regarded as negative aspects of support (seven studies). Several parenting variables included both positive and negative aspects of support, such as 'parental acceptance' (low scores reflect rejection and high scores reflect acceptance) and 'parental care' (low scores reflect parental neglect and rejection and high scores reflect warmth and understanding). These parenting variables were considered as a separate category (18 studies). Studies on negative aspects of support resulted in significantly higher 
effect sizes $(\mathrm{ES} r=0.30, p<0.001, k=7)$ than studies on positive aspects of support ( $\mathrm{ES} r=-0.17, p<0.001, k=47$ ). The mean effect size of these sets of results appeared to be significantly different $\left(Q_{b}(1)=4.30, p<0.05\right)$.

Fail-safe numbers were calculated for each parenting category in order to estimate the number of unpublished non-significant studies that would have to have been found in order to decrease the combined effect size to nonsignificant. If the critical value suggested by Rosenthal (1991) is $5 k+10$ is not exceeded, a file drawer problem is indicated. Fail safe numbers $(p=0.05)$ ranged from 534 to 34,771 and exceeded the critical value. Possible file drawer problems were therefore not indicated and the significance levels of the effect sizes can be considered robust.

Parenting Styles Studies on parenting styles were classified into the category general parenting (Table 2; $\mathrm{ES} r=-0.17$ ). Very few studies analyzed specific parenting styles (Avenevoli et al. 1999; Hoeve et al. 2007; Simons et al. 2005; Steinberg et al. 1991) and surprisingly only one study included neglectful parenting (Avenevoli et al. 1999); therefore, we were only able to compute a mean effect size for authoritative parenting style $(\mathrm{ES} r=-0.19, p<0.001, k=4)$. Only the study by Avenevoli and colleagues (1999) analyzed all four parenting styles in relation to delinquency, including neglectful parenting $(r=-0.20$ for intact families and $r=-0.17$ for single-parent families). Thus, given the small number of previous studies on parenting styles and delinquency, definite conclusions on whether parenting styles have stronger links to delinquency than parenting dimensions or which parenting style has the strongest link to delinquency cannot be drawn.

Discrete Parenting Behaviors Because the parenting dimensions categories are rather broad and knowledge on potential links between discrete parenting behaviors may be useful for investigating which specific child-rearing characteristics could be effective ingredients of interventions, we further analyzed smaller sets of analyses (see the Appendix, second column). If at least three analyses were available we calculated mean effect sizes on discrete parenting behaviors (Table 2). Furthermore, we tested whether mean effect sizes concerning discrete parenting behaviors were significantly different within a parenting dimension. These analyses revealed that the results of various aspects of support differed significantly $\left(Q_{b}(4)=15.3\right.$, $p<0.01)$. For example, we found a trend for a weak link between open communication and delinquency ( $\mathrm{ES} r=-0.07$, $p<0.10, k=11$ ), while supportive parenting was moderately linked to delinquency $(\mathrm{ES} r=-0.23, p<0.001, k=5)$ and negative aspects of support, such as combinations of neglect, hostility and rejection were strongly linked to delinquency $(\mathrm{ES} r=0.33, p<0.001, k=3$ ).
The magnitude of mean effect sizes varied considerably within the parenting dimension behavioral control (Table 2). For example, a significant but small link between permissiveness and delinquency was found $(\mathrm{ES} r=0.09, p<0.05$, $k=10$ ), whereas monitoring was found to have a significant moderate association to delinquency $(\mathrm{ES} r=-0.23, p<0.001$, $k=28)$. Differences in these effect sizes, however, were not significant $\left(Q_{b}(4)=7.2, p>0.05\right)$.

Within the remaining parenting dimensions (i.e., authoritative, authoritarian and psychological control), mean effect sizes of discrete parenting behaviors were relatively similar (Table 2). With respect to authoritarian control, mean effect sizes were relatively small, such as the link between physical punishment and delinquency $(\mathrm{ES} r=0.10$, $p<0.01, k=12$ ). The link between a combination of aspects of authoritarian control and delinquency was slightly stronger $(\mathrm{ES} r=0.16, p<0.001, k=24)$. However, these mean effect sizes did not differ significantly $\left(Q_{b}(2)=3.5, p>\right.$ $0.05)$. Mean effect sizes within authoritative control such as of rewarding and inductive parenting were relatively similar in strength and ranged from -0.11 to -0.13 (Table 2). Moderate effect sizes were found for psychological control $(\mathrm{ES} r=0.21, p<0.001, k=13)$ and overprotection ( $\mathrm{ES} r=$ $0.21, p<0.001, k=7)$. Again, these mean effect sizes did not differ significantly $\left(Q_{b}(2)=3.5, p>0.05\right)$.

Indirect parenting behavior, which refers to parental knowledge and child disclosure, had a significant negative relationship with delinquent behavior ( $\mathrm{ES} r=-0.26, p<0.001$, $k=47$, for knowledge and $\mathrm{ES} r=-0.31, p<0.001, k=11$ for child disclosure). The link between these variables and delinquency was relatively the same as the link between parental monitoring and delinquency $(\mathrm{ES} r=-0.23, p<0.001$, $k=28$ for monitoring; $Q(2)=0.7, p>0.10)$.

The remaining parenting behaviors (category: other parenting) ranged from $r=-0.04, p>0.10$, for parental expectations (i.e., expecting the child to clean his or her bedroom, do the dishes, etc.) to $r=-0.35, p<0.05$, for maternal problem solving statements during an interactive task with the child. A mean effect size was only computed for co-parenting as at least three studies focused on the link between this aspect of parenting and delinquency. A lack of parental agreement in upbringing was significantly related to delinquency $(\mathrm{ES} r=-0.13, p<0.001, k=4)$.

In sum, the strongest mean effect sizes were found for negative aspects of support such as neglect, hostility and rejection or combinations of these parenting behaviors ( $\mathrm{ES} r$ ranges from 0.26 to 0.33). In addition, parental monitoring, either active monitoring by parents, parental knowledge or child disclosure, was relatively strongly linked to delinquency ( $\mathrm{ES} r$ ranges from -0.23 to -0.31 ). Furthermore, moderate effect sizes were found for psychological control and overprotection ( $\mathrm{ES} r$ ranges from 0.21 to 0.23 ). The smallest effect sizes were found for 
communication ( $\mathrm{ES} r=-0.07)$, permissiveness $(\mathrm{ES} r=0.09)$, and physical punishment $(\mathrm{ES} r=0.10)$.

\section{Moderator Analyses}

Because the effect sizes in each of the parenting dimensions, general parenting and indirect parenting categories all had significant within-group variability (Table 2), moderator analyses were conducted for all broader parenting categories. We analyzed both categorical moderators such as gender of the subjects and design of the study and continuous moderators such as year of publication and number of measurements. Moderator analyses using categorical moderators were only conducted if both groups of the moderator included at least three studies. The significant results of the moderator analyses on discrete variables are presented in Table 3 and those on continuous variables in Table 4. Trends are only presented in the text. Results are reported separately for each moderator or group of moderators.

Sex-Differences We did not find any differences between males and females with respect to the link between parenting and delinquency. However, we found some differences between the link between delinquency and paternal and maternal parenting (Table 3-actor). Fathers' supportive behavior was more strongly related to delinquency ( $\mathrm{ES} r=$ $-0.22, p<0.001, k=20)$ than mothers' support $(\mathrm{ES} r=-0.14$, $p<0.001, k=20$ ). In order to analyze whether parents had more influence on a child with the same sex, we created a new moderator with the following categories: (1) fatherssons and mothers-daughters, (2) fathers-daughters and mothers-sons. Because some groups did not meet our criterion of three studies, this moderator analysis could only be conducted with regard to three parenting dimensions. Within the category support this moderator was significant. The link between support and delinquency was stronger for fathers and sons and mothers and daughters $(\mathrm{ES} r=-0.27$, $p<0.001, k=13$ for same sex versus $\mathrm{ES} r=-0.08, p>0.10, k=$ 4 for different sex).

Short-Term vs. Long-Term Associations The moderators time interval between the measurements and design were nonsignificant, indicating that the parenting-delinquency link was relatively similar in longitudinal and crosssectional studies. Because the participant's age does not remain constant in longitudinal studies and is not representative in retrospective studies, we removed the longitudinal and retrospective studies and conducted the moderator analyses on the cross-sectional studies only (Table 4). Significant effects of age were found on general parenting $(z=-2.05, p<0.05, k=9)$. The relationship between general parenting and delinquency was found to be stronger in younger adolescents and school age children than for older adolescents.

Delinquency Type and Source The moderator delinquency type was analyzed comparing studies on overt delinquency,
Table 3 Results of ANOVA for Discrete Moderators

Note. ESr refers to the mean effect size and can be interpreted as a correlation $r . Q_{b}=$ betweenclass homogeneity statistic

${ }^{\mathrm{a}}$ The number between parenthesis indicates the total number of analyses conducted for the moderator

${ }^{*} p<0.05,{ }^{* *} p<0.01$, $* * * p<0.001$

\begin{tabular}{|c|c|c|c|c|}
\hline \multirow[t]{2}{*}{ Group } & \multicolumn{4}{|c|}{ Moderator } \\
\hline & $\begin{array}{l}\text { Subjects } \\
(N)\end{array}$ & $\begin{array}{l}\text { Studies } \\
(k)\end{array}$ & $\mathrm{ES} r$ & $Q_{b}$ \\
\hline \multicolumn{5}{|l|}{ Delinquency type $(3)^{\mathrm{a}}$} \\
\hline Indirect parenting behavior & & & & $4.58 *$ \\
\hline Overt & 4,256 & 5 & $-0.23 * * *$ & \\
\hline Covert & 4,155 & 3 & -0.07 & \\
\hline \multicolumn{5}{|l|}{ Actor (7) } \\
\hline Support & & & & $4.06^{*}$ \\
\hline Mother & 6,711 & 20 & $-0.14 * * *$ & \\
\hline Father & 11,778 & 20 & $-0.22 * * *$ & \\
\hline \multicolumn{5}{|l|}{ Parent and child same sex (3) } \\
\hline Support & & & & $4.05 *$ \\
\hline Different sex & 1,170 & 4 & -0.08 & \\
\hline Same sex & 4,881 & 13 & $-0.27 * * *$ & \\
\hline \multicolumn{5}{|l|}{ Informant (5) } \\
\hline Authoritarian control & & & & $12.16^{* *}$ \\
\hline Parent & 5,681 & 10 & 0.05 & \\
\hline Child & 11,749 & 23 & $0.17 * * *$ & \\
\hline More than one informant & 3,935 & 5 & 0.05 & \\
\hline
\end{tabular}


Table 4 Results of Regression Analyses for Continuous Moderators

${ }^{\mathrm{a}}$ The number between parenthesis indicates the total number of analyses conducted for the moderator

${ }^{*} p<0.05, * * p<0.01$

\begin{tabular}{|c|c|c|c|c|}
\hline \multirow[t]{2}{*}{ Category } & \multicolumn{4}{|l|}{ Moderator } \\
\hline & Subjects $(N)$ & Studies $(k)$ & $Z$ & Beta \\
\hline \multicolumn{5}{|l|}{ Delinquency seriousness $(8)^{\mathrm{a}}$} \\
\hline \multicolumn{5}{|l|}{ Percentage of problem behavior } \\
\hline Indirect parenting behavior & 32,336 & 41 & $2.36^{*}$ & 0.39 \\
\hline \multicolumn{5}{|l|}{ Age $(8)$} \\
\hline \multicolumn{5}{|l|}{ Age (cross-sectional studies) } \\
\hline General parenting & 12,448 & 9 & $-2.05^{*}$ & -0.55 \\
\hline \multicolumn{5}{|l|}{ Methodological characteristics (8) } \\
\hline \multicolumn{5}{|l|}{ Impact factor } \\
\hline Authoritative control & 7,893 & 12 & $-1.90^{*}$ & -0.48 \\
\hline General control & 3,791 & 10 & $-2.28^{*}$ & -0.65 \\
\hline \multicolumn{5}{|l|}{ Reliability (parenting measure) } \\
\hline Indirect parenting behavior & 21,834 & 30 & $2.76^{* *}$ & 0.47 \\
\hline
\end{tabular}

such as violent offences, and covert delinquency, such as car theft or vandalism (Table 3). Because most studies focused on general delinquency and to a much lesser extent on overt or covert delinquency we were able to conduct moderator analyses for only two parenting dimensions (support and indirect parenting). A significant difference was found between studies that measured overt delinquency and studies that analyzed covert delinquency in relation to indirect parenting behavior (knowledge and child disclosure). Studies on overt delinquency resulted in stronger links between parental knowledge and child disclosure and delinquency $(\mathrm{ES} r=-0.23, p<0.001, k=5$ vs. $\mathrm{ES} r=-0.07$, $p>0.10, k=3$ ). We expected studies that used questionnaires with items on non-illegal problem behavior to result in weaker effect sizes than measures reporting illegal offences only. Instead, effect sizes in the studies with measures including a higher proportion of non-illegal problem behaviors were stronger in the category indirect parenting behavior $(z=2.36, p<0.05, k=41)$. Thus, studies on parental knowledge and child disclosure resulted in stronger effect sizes if delinquency questionnaires included relatively more items on non-illegal problem behavior (Table 4). The source of delinquency was not associated with effect size, indicating that no significant differences were found between studies using self-reported delinquency and studies relying on official delinquency.

Informant of Parenting Behavior Moderator analyses were performed in five categories of parenting dimensions with regard to the informant of parenting (Table 3). This moderator was significant with respect to authoritarian control. The studies on authoritarian control in which the child reported on the level of authoritarian discipline techniques, yielded significantly stronger associations than studies with a parent as informant $(\mathrm{ESr}=0.05, p>0.10, k=10$, parent informants vs.
$\mathrm{ES} r=.17, p<0.001, k=23$, child informants, $\mathrm{ES} r=0.05$, $p>0.10, k=5$, more than one informant respectively).

Study Quality and Methodological Characteristics Following Mullen's (Mullen, 1989) advice to include studies of varying quality, no studies were excluded on the basis of the quality of their design. The reason for this is that assessing the quality of a study appropriately is complicated and often problematic. Instead, we examined study characteristics that address the issue of study quality as moderators such as sample size and reliability of parenting questionnaires. The following moderators that might refer to the study quality were analyzed: publication status, impact factor, sample size, number of items in the delinquency measure, number of items in the parenting measure, and reliability of the parenting measure. Because information about the reliability of the delinquency measure was unavailable most of the time, this study characteristic was not examined. Impact factor was significant in two parenting dimensions: authoritative control $(z=-1.90$, $p<0.06, k=12)$ and general control $(z=-2.28, p<0.05$, $k=10$ ). Studies published in journals with a high impact factor reported smaller effect sizes than studies in low impact journals (Table 4). We found a trend for the moderator sample size in the parenting category indirect parenting behavior $(z=-1.72, p<0.10, k=51)$. Studies with smaller sample sizes showed a larger effect size than studies with larger numbers of subjects. For the number of delinquency items in a questionnaire we found a trend in the category psychological control $(z=1.68, p<0.10, k=19)$, indicating that stronger links between psychological control and delinquency were found in studies that used measures with a larger number of items on delinquent acts. Reliability of the parenting measure was a significant moderator in one category: indirect parenting behavior $(z=2.76, p<0.01$, 
$k=30)$. We found a trend in the category authoritative parenting $(z=1.92, p<0.10, k=12)$, indicating a trend for the link between higher reliabilities and larger effect sizes. Publication status and number of parenting items did not moderate the effect size. Given that the study quality of retrospective studies is often questioned we conducted several analyses in order to investigate the potential influence of these studies. As mentioned above, study design was not associated with effect size. In addition, the recalculation of the mean effect sizes of studies excluding those with a retrospective design, did not lead to different conclusions, probably because there were so few retrospective studies.

\section{Discussion}

In the present meta-analysis we tested the connection between parenting and delinquency. We focused on parenting from different perspectives, analyzing parenting dimensions, styles and behaviors in relation to delinquency. The first goal was to investigate what the magnitudes of these associations are and which of these have the strongest relationships with delinquent behavior. The second purpose was to analyze potential moderators of the parentingdelinquency link and their relative importance.

This meta-analysis confirms that parenting is related to delinquency. We found significant links between all parenting dimensions and delinquency but the magnitude of the relation depended on the particular parenting dimension. The strongest links were found for psychological control $(\mathrm{ES} r=0.23)$ and the weakest links were found for authoritative and authoritarian control $(\mathrm{ESr}=0.12)$. Analyzing discrete parenting behaviors (i.e., subcategories within parenting dimensions) revealed that differences were even larger. The strongest mean effect sizes were found for negative aspects of support such as neglect, hostility and rejection or combinations of these parenting behaviors ( $\mathrm{ES} r$ ranges from 0.26 to 0.33 ). In addition, parental monitoring, either active monitoring by parents, parental knowledge or child disclosure, was relatively strongly linked to delinquency ( $\mathrm{ES} r$ ranges from -0.23 to -0.31 ). These results are in accordance with the finding of Loeber and StouthamerLoeber (1986) that parental rejection and poor supervision were among the best predictors of delinquency. Furthermore, moderate effect sizes were found for psychological control and overprotection ( $\mathrm{ES} r$ ranges from 0.21 to 0.23 ). The smallest effect sizes were found for communication $(\mathrm{ES} r=-0.07)$, permissiveness $(\mathrm{ES} r=0.09)$, and physical punishment $(\mathrm{ES} r=0.10)$. Parenting accounted for up to $11 \%$ of the variance in delinquency.

The magnitude of the effect sizes ranged from small to moderate. It should be noted that even small effect sizes, such as the link between authoritarian control and delinquency can have substantively important consequences. The practical importance of a correlation can be shown in a Binomial Effect Size Display (BESD, McCartney and Rosenthal 2000). For example, consider a group of 200 youngsters of which half of these youngsters have authoritarian parents and half do not. A correlation of 0.12 can be displayed as follows: $44 \%$ of the youngsters without authoritarian parents versus $56 \%$ of the youngsters with authoritarian parents show delinquent behavior. A correlation of 0.33 such as of the link between negative aspects of support (neglect, hostility and rejection) and delinquency can be displayed as follows: $67 \%$ of the youngsters with parents that adopt a rejecting and hostile attitude versus only $33 \%$ of the youngsters with parents who do not or hardly employ these seriously negative parenting behaviors will score high on delinquency. These are substantively important effects.

Given that both parenting dimensions of support and control were linked to delinquent behavior, parenting styles could be important risk factors for delinquency (that is, the combination of the dimensions support and control). In particular, a neglectful parenting style may be linked to delinquency (Maccoby and Martin 1983; Steinberg et al. 1994). Although hardly any studies were found on the link between a neglectful parenting style and delinquency, studies that measured parental neglect unidimensionally resulted in strong links between neglectfulness and delinquency $(\mathrm{ES} r=0.29)$.

The results of this meta-analysis have implications for theories on parenting. Analyzing parenting dimensions, we found significant differences between various types of control including authoritative, authoritarian, behavioral and psychological control, with the highest effect sizes for psychological control. Based on these findings we agree with Barber et al. (1994) that it is useful to consider psychological control and nonpsychological assertive control (i.e. authoritarian control in this meta-analysis) as separate forms of control. However, contrary to the finding of Barber et al. (1994) that behavioral control rather than psychological control is responsible for increased levels of delinquency, we found that psychological control is as least as important as behavioral control. A possible explanation could be that we focused on delinquency including at least some serious offences, while Barber et al. (1994) focused on delinquency that included a relatively limited range of minor delinquent acts. ${ }^{4}$ Nevertheless, our findings clearly indicate that psychological control, including keeping the

\footnotetext{
${ }^{4}$ Notice also that the number of items in the delinquency questionnaire moderated the link between psychological control and delinquency in our meta-analysis: the more items, the stronger the effect size.
} 
child dependent and the use of guilt to control the child, elevates the risk for delinquent behavior.

Extremely negative behaviors such as rejection, neglect and hostility were linked to delinquency. Youngsters who experience rejection by significant others such as parents are at risk to develop distorted mental representations of themselves and their environment (Rohner 2004), which may explain why these youngsters are more likely to show delinquent behavior. The negative aspects of support had significantly stronger links to delinquency than a lack of support and warmth. These findings have implications for theories that model the support dimension of parenting as a continuum with one end referring to positive aspects such as warmth, affection and acceptance and the other end referring to the absence of these positive behaviors and the presence of negative aspects of support (e.g., Rohner 2004). The present meta-analysis shows that negative aspects of support have different links to delinquency than the positive aspects and therefore these concepts should be considered as separate parenting dimensions.

Poor parental monitoring was also relatively strongly linked to delinquency. The three indicators of parental monitoring, that is, parental knowledge of the child's whereabouts, the active tracking and tracing of the child's whereabouts by parents, and child disclosure, had links to delinquency that were relatively similar in magnitude. Stattin and Kerr (2000) suggested that the link between parental knowledge and delinquency can be explained by the child's disclosure of his or her activities and whereabouts, rather than actual tracking behavior by the parent. Actual monitoring by parents is probably limited, because adolescents spend less time with their parents and are relatively autonomous (Hirschi 1969; Nye 1958; Stattin and Kerr 2000). Therefore, we expected that the link between child disclosure and delinquency would be stronger than the link between poor parental monitoring and delinquency, however, the present meta-analysis revealed relatively similar effect sizes. Thus, both the child and the parent are active agents in the process of the link between knowledge on whereabouts of the child and delinquency.

In addition to theoretical implications, our results concerning the link between discrete parenting behaviors (monitoring, neglectfulness, rejection) and delinquency have implications for intervention and prevention policies focusing on delinquency, in particular parent management training programs. Programs should focus on training parents to actively monitor and guide their children in order to enhance parents' knowledge on the whereabouts of children. Although parent management training programs exist in many variations, typical trainings primarily do focus on improving parental discipline techniques and monitoring (Patterson 1982). Given that a large effect size was found for child disclosure, the emphasis in parent trainings should also lay on improvements in the relationship and trust, given that this enhances disclosure. Furthermore, practitioners should be alert to parents who are neglecting and have a hostile and rejecting attitude towards their children, since combinations of these parenting behaviors are strongly linked to higher levels of delinquent behavior in youngsters. Translating the present results into a Binomial Effect Size Display (McCartney and Rosenthal 2000) suggests that if parent management training programs succeed in improving parenting practices, up to $33 \%$ of the youngsters of the successful parents may desist from delinquent behavior. Our finding concerning the significance of the link between parenting and delinquency is in line with studies that found support for the effectiveness of parent management training programs in reducing delinquency and antisocial behavior (e.g., McCart et al. 2006; Mulford and Redding 2008).

Sex-differences were found regarding the parentingdelinquency association. We found stronger links between poor support and delinquency in same-sex parent-child pairs. Poor support of father to sons and poor support of mothers to daughters were more strongly linked to delinquency than cross-gender supportive behavior by parents. An explanation could be that children have the tendency to identify with the same-sex parent (Laible and Carlo 2004), and a good relation with this parent serves as a protective factor against delinquency. We also found that poor paternal support was more strongly related to delinquency than poor maternal support. This finding may be particularly applicable to boys. Given the lack of studies that investigate fathers and that boys are more often delinquent than girls, there appears to be a serious gap in research. Our findings suggest that fathers may even have more influence on their sons' delinquency than mothers, supporting the contention that it is important to work with fathers when treating delinquency in boys. This is in line with a recent meta-analysis showing that children benefited more if fathers attended a parent training compared to programs that focused on mothers only (Lundahl et al. 2008).

Our findings from the moderator-analyses on age have important implications for the current debate between scholars from static versus dynamic theories on the causes of delinquent behavior (Hirschi and Gottfredson 2001; Sampson and Laub 2001a, b). In the present meta-analysis significant effects of age were found in cross-sectional studies on general parenting, indicating that correlates are not the same at all ages. This is in contradiction with assumptions of static models, but is in line with the dynamic models, such as the theory of Sampson and Laub $(1993,2005)$ suggesting that correlates of delinquency may change during the life-course. We found that the association between general parenting and delinquency was stronger in 
school age children and early adolescents compared to mid and late adolescents. The parenting-delinquency link may weaken as children mature with the influence of peers or other life events having more impact. According to Sampson and Laub, changes in life circumstances are able to generate turning points in an individual's criminal career. Delinquent behavior is inhibited during childhood and adolescence by bonds to the family and school. During (young) adulthood, social ties to labor or marriage and other turning points in life can modify trajectories of criminal offending. Thus, the findings in the present metaanalysis favor dynamic theories.

Different effect sizes were found depending on the informant about parenting. Studies in which the children reported on the level of authoritarian control found significantly stronger results than studies in which the parents were the informants or in which several different informants reported on this parenting dimension. We offer the following possible explanation for this finding. Children are more likely to indicate negative characteristics of their family, whereas parents tend to overestimate positive characteristics of their parenting behavior (Noller and Callan 1988). Additionally, dissimilar views of parents and children have been found to reflect stress and conflict and are associated with child maladjustment (Carlson et al. 1991). The stronger effect sizes for child report measures may be due to more negative views of youngsters who engage in delinquency and not to actual parenting differences per se. To our knowledge it is unknown which informants provide the most realistic information on parenting. These findings are important as the majority of studies rely on reports of children instead of parents (69\% in the present meta-analysis) and only $3 \%$ of studies actually used observed parent-child interactions. Researchers collecting information on parenting should take the effects of different informants on parenting-delinquency associations into consideration when they interpret their findings and should control for social desirability of informants.

We found some evidence for significant methodological moderators. For example, the number of items in parenting and delinquency questionnaires did moderate the parenting-delinquency link. If questionnaires had relatively many items, stronger links were found between psychological control and delinquency. Also, stronger effects were found in studies that used more reliable parenting questionnaires. As expected, these findings indicate that if the quality of studies is higher, stronger links will be found between parenting dimensions and delinquency. Thus, these results demonstrate the importance of using reliable and validated questionnaires. Given that we included studies that ranged in quality, the mean effect sizes in this meta-analysis may be conservative.
Limitations

It should also be noted that, for reasons of comparability, we focused on studies analyzing bivariate associations. Nevertheless, studies have been published that conducted multivariate analysis to test a prediction model for delinquent behavior. Multivariate analyses give insight to the unique contribution of parenting characteristics to delinquency by simultaneously controlling for other factors. However, metaanalyzing multivariate associations is problematic, because the effect size statistics of interest depend on what other variables are in the multivariate model (Lipsey and Wilson 2001). Multivariate models that are comparable across studies are rare. Further limitations of this meta-analysis are related to the poor availability of studies with specific characteristics. These gaps in research are discussed below.

\section{Gaps in Research}

Unfortunately, as a result of the dearth of the studies that have actually examined parenting styles, we were not able to calculate mean effect sizes for various parenting styles. Future studies should extend research on parenting styles and delinquency in order to clarify whether these combinations of parenting characteristics have stronger associations with delinquency than only single dimensions. In particular, studies should include neglectful and permissive styles, and not only focus on authoritarian and authoritative parenting styles.

The vast majority of studies did not report separate effect sizes for different ethnic groups. Generally, studies only reported the percentage of several ethnic minority groups in the sample. Given that ethnic minority groups each may differ in style of parenting and in the prevalence of delinquency, analyzing ethnicity as a moderator would be of interest. In order to get insight into potential differences in the parentingdelinquency link between ethnic groups, it would be helpful if future studies would report effect sizes for each ethnic group.

The vast majority of studies $(87 \%)$ had short time interval (less than 5 years) or were cross-sectional, which makes it difficult to get a clear picture of the longer term effects of parenting. Some previous studies, including timeintervals of at least 10 years suggest that parenting influences delinquent behavior in youngsters, but the influence of parents weakens over time (Hoeve et al. 2007, 2008). Further research is needed to provide information on parental correlates of delinquency across developmental levels. Most studies were focused on adolescents despite the fact that many models emphasize the role of parenting during childhood (e.g., Gottfredson and Hirschi 1990; Moffitt and Caspi 2001; Sampson and Laub 1993). Another reason for the need of additional longitudinal studies that cover a longer time span is to test typological theories of delinquency. For example, Moffitt 
(1993) identified two types of offenders: life-coursepersistent offenders, which originate early in life, and adolescence-limited delinquents, which begin around puberty. Life-course-persistent delinquents were found to be associated with poor parenting, whereas adolescencelimited delinquents were not (Moffitt and Caspi 2001). Given the assumptions of Moffitt and Caspi's taxonomy, one would expect to find stronger links between inadequate parenting and persistent offending than the parentingdelinquency links found in the present meta-analysis (i.e., delinquency at one point in time). Finally, longitudinal studies are needed to demonstrate whether or not parenting factors contribute to the continuation of offending after onset or for later onsets after age 20 (Farrington 2005).

From our meta-analysis it became clear that studies generally focus on one parent or both parents without differentiating between the sex of the parent $(58 \%$ of the studies). The present meta-analysis, however, shows that it is worthwhile to compare studies on fathers with studies on mothers and their children. Future studies should make an effort to involve both fathers and mothers in their investigations and more clearly distinguish between father's and mother's reports on parenting when analyzing the link between parenting and delinquency.

The longitudinal studies included in our meta-analysis measured parenting at an earlier point in time than delinquency, hypothesizing that poor parenting leads to offspring delinquency. However, parents not only influence their children, but children also influence their parents (Crouter and Booth 2003; Granic 2000; Holden 1997). Most parents change their discipline practices if they notice that their child has committed a delinquent act (Kerr and Stattin 2003). Even though the included longitudinal studies showed that poorer parenting practices preceded delinquent behavior, a bidirectional view on parent-child relations cannot be rejected as we do not know whether the child-rearing characteristics had been influenced by earlier delinquency or other problem behaviors of the child. Thus, the direction of causal influence may run both ways. Therefore, we should not rule out that the link between parenting and delinquency may also be due to the impact of delinquency on parenting. If future longitudinal studies would test whether delinquency affects parenting, a metaanalysis could compare child and parent effects in the parenting-delinquency link.

The moderator analysis revealed that parental monitoring (at least knowledge and child disclosure) is relatively strongly linked to overt delinquency. We found that studies on overt delinquency, such as violent offences, found stronger links between poor child disclosure and parental knowledge on the child's whereabouts and delinquency than studies on covert delinquency, such as theft and arson. Moffitt and Caspi (2001) found that chronic offenders are more likely to be engaged in overt delinquency and have more family-related problems than youngsters who show primarily covert delinquent behavior temporarily during adolescence. Therefore, parental monitoring may be an important predictor for persistent overt delinquency. However, this finding should be interpreted with caution as only three studies focused on parental knowledge, child disclosure and covert delinquency. Given that parenting may be differentially linked to overt and covert delinquency (see also, Loeber et al. 2008), future studies on delinquency should distinguish between overt and covert behaviors.

\section{Conclusions}

This meta-analysis demonstrates that a significant relationship exists between parenting and delinquency and confirms previous research that behavioral control, such as parental monitoring is negatively linked to delinquency (Barber 1996; Patterson and Yoerger 1993). Moreover, this meta-analysis revealed that negative aspects of support including rejection, hostility and neglect and psychological control had the strongest links to delinquency. Furthermore, several indicators of parental monitoring, including parental knowledge, child disclosure, and active monitoring by parents, had similar links to delinquency.

Important study characteristics including sex of children and parents, age of the participants, delinquency type, and informant on parenting were significant moderators, indicating that some parenting dimensions are more crucial in particular situations or for particular subsamples. A lack of support had a relatively strong link to delinquency if that parent and child were the same sex. In addition, the parentingdelinquency link was stronger in school age children and early adolescents than in older adolescents. Furthermore, parental monitoring was more strongly linked to overt delinquency that covert delinquency, stressing the importance of distinguishing between different types of delinquency. Finally, larger effects were found when children reported on parenting than when parent self reports were used.

These findings have important implications for intervention and prevention policies focusing on delinquency. Interventions should not only focus on aspects of behavioral control such as restrictiveness, consistency in discipline, and monitoring, but should also target parenting dimensions such as psychological control and negative aspects of support. Furthermore, our findings suggest that fathers should be involved in intervention programs for violent youth, particularly interventions aimed at delinquent boys and if fathers themselves are not offenders. Finally, the finding that parenting is more strongly linked to delinquency in school age children and early adolescents, stresses the importance of prevention strategies early in life. 
Acknowledgements We thank Peter van der Voort for helping us collecting copies of the manuscripts and Maja Deković, Rolf Loeber, Magda Stouthamer for advising us about additional relevant studies. We also thank Marlies van Dijk and Tamara Verbeek, who coded the family variables, and Geert Jan Stams, David Farrington and Henk Elffers who gave advice on statistical matters.
Open Access This article is distributed under the terms of the Creative Commons Attribution Noncommercial License which permits any noncommercial use, distribution, and reproduction in any medium, provided the original author(s) and source are credited.

\section{Appendix}

Table 5 List of Parenting Categories

\begin{tabular}{lll}
\hline Category & Parenting behaviors $\quad$ Names and words in description \\
\hline
\end{tabular}

Parenting dimensions

Support

Acceptance

Affection

Responsiveness

Sensitivity

Involvement

Parental trust

Understanding

Nurturance

Supportive parenting

Praise

Open communication

Support positive (class)

Avoidant offensive communication (-)

Underconcern (-)
Acceptance

Feels wanted

Affection

Affective tie

Hugs

Loving

Positive feelings

Smiles

Warmth

Involvement

Attention

Pay attention

Care

Confide

Reliability

Trust

Emotional support

Instrumental support

Support

Communication

Quality of communication

Communication (frequency)

Intimate communication

Open communication

Parental self-disclosure

Talks

Instrumental communication

Consists of more than one positive aspect of support

(e.g., acceptance, involvement, and understanding)

Avoidant communication

Offensive communication

Bad reaction to communication

Indifference

Underconcern 
Table 5 (continued)

\begin{tabular}{|c|c|c|}
\hline Category & Parenting behaviors & Names and words in description \\
\hline & Neglectful (-) & Neglect \\
\hline & & Alienation \\
\hline & & Avoidance \\
\hline & Rejection (-) & Rejection \\
\hline & Hostility (-) & Hostility \\
\hline & & Anger \\
\hline & & Annoyance \\
\hline & & Irritation \\
\hline & & Sarcasm \\
\hline & Anxious emotional involvement (-) & \\
\hline & Cruel passive attitude $(-)$ & \\
\hline & Discouragement $(-)$ & \\
\hline & Support negative (class) $(-)$ & $\begin{array}{l}\text { Consists of more than one negative aspect of support } \\
\text { (e.g., rejection and hostility) }\end{array}$ \\
\hline \multirow[t]{10}{*}{ Authoritative control } & Rewarding & Noticing when doing good \\
\hline & & Positive parenting \\
\hline & & Rewarding \\
\hline & & Reinforcement \\
\hline & Inductive parenting & Calmly discuss misbehavior \\
\hline & & Democratic \\
\hline & & Inductive parenting \\
\hline & & Reasoning \\
\hline & Nonpunitive techniques & \\
\hline & Authoritative control (class) & $\begin{array}{l}\text { Consists of more than one aspect of authoritative control } \\
\text { (e.g., rewarding, inductive parenting, and consistent discipline) }\end{array}$ \\
\hline \multirow[t]{24}{*}{ Authoritarian control } & Harsh discipline & Firm control \\
\hline & & Harsh discipline \\
\hline & Physical punishment & Beaten child up \\
\hline & & Hitting \\
\hline & & Kicking \\
\hline & & Physical power assertive discipline \\
\hline & & Slapping \\
\hline & & Threatening to hit \\
\hline & & Physical punishment \\
\hline & & Spanking \\
\hline & Verbal aggression as punishment & Abusive name calling \\
\hline & & Aversive parenting \\
\hline & & Nagging \\
\hline & & Scolding \\
\hline & & Yelling \\
\hline & & Verbal attacks \\
\hline & & Control of anger toward child \\
\hline & & Shouting \\
\hline & Punishment & Withdrawal of privileges \\
\hline & & Punishment \\
\hline & & Dominative parenting \\
\hline & Reinforce aggression & \\
\hline & Rigidity & \\
\hline & Power-assertiveness & \\
\hline
\end{tabular}


Table 5 (continued)

\begin{tabular}{|c|c|c|}
\hline Category & Parenting behaviors & Names and words in description \\
\hline & Unreasoning & \\
\hline & Authoritarian control (class) & $\begin{array}{l}\text { Consists of more than one aspect of authoritarian } \\
\text { control (e.g., physical punishment, and } \\
\text { inconsistent discipline) }\end{array}$ \\
\hline & & Poor discipline \\
\hline & & Authoritarian parenting (no style) \\
\hline \multirow[t]{22}{*}{ Behavioral control } & Control & Control \\
\hline & & Discipline \\
\hline & Rules setting & Rules management \\
\hline & & Rules setting \\
\hline & Decision making & \\
\hline & Restrictiveness & Demanding \\
\hline & & Demands for conformity \\
\hline & & Restrictiveness \\
\hline & Monitoring & Monitoring \\
\hline & & Supervision \\
\hline & & Tracking of activities \\
\hline & & Tracking of whereabouts \\
\hline & Checking homework & \\
\hline & Consistent discipline & Consistent discipline \\
\hline & & Follow-through \\
\hline & Inconsistent discipline $(-)$ & Erratic \\
\hline & & Inconsistent discipline \\
\hline & & Uncertainty and confusion \\
\hline & Permissiveness $(-)$ & Ignoring wrongdoing \\
\hline & & Lax discipline \\
\hline & & Permissiveness \\
\hline & Behavioral control (class) & $\begin{array}{l}\text { Consists of more than one aspect of behavioral control } \\
\text { (e.g., rules setting, restrictiveness, and permissiveness) }\end{array}$ \\
\hline \multirow[t]{13}{*}{ Psychological control } & Psychological control & Often interrupts child \\
\hline & & Tries to change feelings of child \\
\hline & & Psychological control \\
\hline & & Use of guilt to control child \\
\hline & & Emotional withdrawal \\
\hline & & Love withdrawal \\
\hline & & Ignoring as a form of punishment \\
\hline & Overprotection & Dependence \\
\hline & & Overprotection \\
\hline & & Intrusion \\
\hline & & Protecting \\
\hline & Autonomy (-) & Autonomy \\
\hline & Psychological control (class) & $\begin{array}{l}\text { Consists of more than one aspect of psychological control } \\
\text { (e.g., psychological control and autonomy) }\end{array}$ \\
\hline General control & Control (class) & $\begin{array}{l}\text { Consists of more than one control dimension } \\
\text { (e.g., authoritarian control and behavioral control) }\end{array}$ \\
\hline \multicolumn{3}{|l|}{ Parenting styles } \\
\hline \multirow[t]{4}{*}{ General parenting } & Parenting & Consists of both support and control dimensions \\
\hline & & Parenting \\
\hline & & Inadequate parenting \\
\hline & & Effective parenting \\
\hline
\end{tabular}


Table 5 (continued)

\begin{tabular}{lll}
\hline Category & Parenting behaviors & Names and words in description \\
\hline & & Parenting style \\
& Authoritative parenting style & Authoritative parenting \\
Authoritarian parenting style & Authoritarian parenting \\
Permissive parenting style & \\
Neglectful parenting style & & \\
Remaining categories & Knowledge & Knowledge \\
behavior & & Awareness \\
& & Transfer of information from teen to parent \\
& & Awareness of activities \\
Cther parenting & Child disclosure & Child disclosure \\
& Problem-solving & Unfair discipline \\
& fairness & Fair discipline \\
& Co-parenting & Agree on discipline \\
& Expectations & Disagree on discipline \\
& Spend time & Negative expectations
\end{tabular}

\section{References}

*Adams, J. B. (2001). Self-control as a mediator for the effects of parental bonding, prosocial behavioral training and psychological autonomy on adolescent delinquency. Dissertation Abstracts International, 62(4 A), 1595 (UMI No. 3013141).

*Andry, R. G. (1962). Parental affection and delinquency. In M. E. Wolfgang, L. Savitz, \& H. Johnston (Eds.), The sociology of crime and delinquency. New York: Wiley.

*Aseltine, R. H. (1995). A reconsideration of parental and peer influences on adolescent deviance. Journal of Health and Social Behavior, 36(2), 103-121.

*Avenevoli, S., Sessa, F. M., \& Steinberg, L. (1999). Family structure, parenting practices, and adolescent adjustment: An ecological examination. In E. M. Hetherington (Ed.), Coping with divorce, single parenting, and remarriage: A risk and resiliency perspective (pp. 65-90). Mahwah, NJ, USA: Erlbaum.

Babinski, L. M., Hartsough, C. S., \& Lambert, N. M. (2001). A comparison of self-report of criminal involvement and official arrest records. Aggressive Behavior, 27(1), 44-54.

*Bailey, B. N., Hannigan, J. H., Delaney Black, V., Covington, C., \& Sokol, R. J. (2006). The role of maternal acceptance in the relation between community violence exposure and child functioning. Journal of Abnormal Child Psychology, 34(1), 54-67.

*Baldry, A. C., \& Farrington, D. P. (2000). Bullies and delinquents: Personal characteristics and parental styles. Journal of Community and Applied Social Psychology, 10(1), 17-31.

*Banyard, V. L., Cross, C., \& Modecki, K. L. (2006). Interpersonal violence in adolescence: Ecological correlates of self-reported perpetration. Journal of Interpersonal Violence, 21(10), 1314-1332.

Barber, B. K. (1996). Parental psychological control: Revisiting a neglected construct. Child Development, 67(6), 3296-3319.

Barber, B. K., Maughan, S. L., \& Olsen, J. A. (2005). Patterns of parenting across adolescence. New Directions for Child and Adolescent Development, 108, 5-16.
Barber, B. K., Olsen, J. E., \& Shagle, S. C. (1994). Associations between parental psychological and behavioral control and youth internalized and externalized behaviors. Child Development, 65 (4), 1120-1136.

*Barberet, R., Rechea-Alberola, C., \& Montanes- Rodriguez, J. (1994). Self-reported juvenile delinquency in Spain. In J. Junger-Tas, G. J. Terlouw, \& M. W. Klein (Eds.), Delinquent behavior among young people in the Western world. Amsterdam: Kugler.

Barnes, G. M., \& Farrell, M. P. (1992). Parental support and control as predictors of adolescent drinking, delinquency, and related problem behaviors. Journal of Marriage and the Family, 54(4), 763-776.

Baumrind, D. (1966). Effects of authoritative control on child behavior. Child Development, 37(4), 887-907.

Baumrind, D. (1968). Authoritarian vs. authoritative parental control. Adolescence, 3(11), 255-272.

Baumrind, D. (1971). Current patterns of parental authority. Developmental Psychology, 4(1), 1-103.

*Bean, R. A., Barber, B. K., \& Crane, D. R. (2006). Parental support, behavioral control, and psychological control among African American youth: The relationships to academic grades, delinquency, and depression. Journal of Family Issues, 27(10), 1335-1355.

*Becker, K. D., Stuewig, J., Herrera, V. M., \& McCloskey, L. A. (2004). A study of firesetting and animal cruelty in children: Family influences and adolescent outcomes. Journal of the American Academy of Child and Adolescent Psychiatry, 43(7), 905-912.

Bessant, J., \& Hil, R. (1998). Parenting on trial: State wards' and governments' accountability in Australia. Journal of Criminal Justice, 26(2), 145-157.

Bonett, D. G. (2007). Transforming odds ratios into correlations for meta-analytic research. American Psychologist, 62(3), 254-255.

*Borduin, C. M. (1985). Verbal problem solving in families of fatherabsent and father-present delinquent boys. Child and Family Behavior Therapy, 7(2), 51-63. 
*Borduin, C. M., Pruitt, J. A., \& Henggeler, S. W. (1986). Family interactions in black, lower-class families with delinquent and nondelinquent adolescent boys. Journal of Genetic Psychology, 147(3), 333-342.

*Born, M., \& Gavray, C. (1994). Self-reported delinquency in Liege, Belgium. In J. Junger-Tas, G. J. Terlouw, \& M. W. Klein (Eds.), Delinquent behavior among young people in the Western world (pp. 130-155). Amsterdan: Kugler.

*Bowman, M. A., Prelow, H. M., \& Weaver, S. R. (2007). Parenting behaviors, association with deviant peers, and delinquency in African American adolescents: A mediated-moderation model. Journal of Youth and Adolescence, 36(4), 517-527.

*Brendgen, M., Vitaro, F., Tremblay, R. E., \& Lavoie, F. (2001). Reactive and proactive aggression: Predictions to physical violence in different contexts and moderating effects of parental monitoring and caregiving behavior. Journal of Abnormal Child Psychology, 29(4), 293-304.

*Burt, C. H., Simons, R. L., \& Somons, L. G. (2006). A longitudinal test of the effects of parenting and the stability of self-control: Negative evidence for the general theory of crime. Criminology, 44(2), 353-396.

*Burton, V. S., Cullen, F. T., Evans, T. D., Dunaway, G. R., Kethineni, S. R., \& Payne, G. L. (1995). The impact of parental controls on delinquency. Journal of Criminal Justice, 23, 111-126.

${ }^{*}$ Caldwell, R. M., Beutler, L. E., Ross, S. A., \& Silver, N. C. (2006). Brief report: An examination of the relationships between parental monitoring, self-esteem and delinquency among Mexican American male adolescents. Journal of Adolescence, 29(3), 459-464.

*Campbell, A. (1987). Self-reported delinquency and home life: Evidence from a sample of British girls. Journal of Youth and Adolescence, 16(2), 167-177.

*Capaldi, D. M., Pears, K. C., Patterson, G. R., \& Owen, L. D. (2003). Continuity of parenting practices across generations in an at-risk sample: A prospective comparison of direct and mediated associations. Journal of Abnormal Child Psychology, 31(2), 127-142.

Carlson, C. I., Cooper, C. R., \& Spradling, V. Y. (1991). Developmental implications of shared versus distinct perceptions of the family in early adolescence. In R. L. Paikoff (Ed.), Shared views in the family during adolescence (vol. Vol. 51, (pp. 13-32)). San Francisco: Jossey-Bass.

*Cernkovich, S. A., \& Giordano, P. C. (1987). Family relationships and delinquency. Criminology, 25(2), 295-321.

*Chapple, C. L. (2003). Examining intergenerational violence: Violent role modeling or weak parental controls. Violence and Victims, 18 (2), 143-162.

*Chung, H. L., \& Steinberg, L. (2006). Relations between neighborhood factors, parenting behaviors, peer deviance, and delinquency among serious juvenile offenders. Developmental Psychology, 42(2), 319-331.

Cohen, J. (1988). Statistical power analysis for the behavioral sciences. New York: Academic.

Colpin, H. (1999). De gezinsopvoeding: Een conceptueel kader [Child-rearing: A conceptual framework]. In L. Vandemeulebroecke, H. Van Crombrugge, \& J. R. M. Gerris (Eds.), Gezinspedagogiek: Actuele thema's in onderzoek en praktijk [Family pedagogy: Current theories and research] (pp. 53-64). Apeldoorn: Garant.

*Cook, E. T. (1996). Risk and protective factors in adolescent problem behaviors. Dissertation Abstracts International, 57, 4742 (Doctoral dissertation, University of Washington, 1996).

Cooper, H. M. (1989). Integrating research: A guide for literature reviews. Newbury Park, CA: Sage.

*Cota Robles, S., \& Gamble, W. (2006). Parent-adolescent processes and reduced risk for delinquency: The effect of gender for Mexican American adolescents. Youth and Society, 37(4), 375-392.
Cottle, C. C., Lee, R. J., \& Heilbrun, K. (2001). The prediction of criminal recidivism in juveniles: A meta-analysis. Criminal Justice and Behavior, 28(3), 367-394.

*Coughlin, C., \& Vuchinich, S. (1996). Family experience in preadolescence and the development of male delinquency. Journal of Marriage and the Family, 58(2), 491-501.

*Criss, M. M. (2002). How parents find out about their teenagers' activities: Validating an observational measure of monitoring as dyadic process. Dissertation Abstracts International, 63(2 B), 1086 (UMI No. 3043993).

Crouter, A. C., \& Booth, A. (2003). Children's influence on family dynamics: The neglected side of family relationships. Mahwah, NJ: Erlbaum.

Darling, N., \& Steinberg, L. (1993). Parenting style as context: An integrative model. Psychological Bulletin, 113(3), 487-496.

*De Kemp, R. A. T., Scholte, R. H. J., Overbeek, G., \& Engels, R. C. M. E. (2004). Opvoeding, delinquente vrienden en delinquent gedrag van jongeren [Parenting, delinquent friends and delinquent behaviour of adolescents]. Pedagogiek, 24(3), 262-278.

*Dekkers, M. E. (1998). Losbandig gezin, losbandige tieners? Een onderzoek naar de invloed van gezinscohesie op risicogedrag van adolescenten. Unpublished Master's thesis, University of Leiden, Leiden, The Netherlands.

*Dekovic, M., Janssens, J. M. A. M., \& Van As, N. M. C. (2001). Gezinsfactoren en het gebruik van ernstig geweld [Family factors and serious violence]. In R. Loeber, N. W. Slot, \& J. A. Sergeant (Eds.), Ernstige en gewelddadige jeugdcriminaliteit: Omvang, oorzaken en interventies [Serious and violent delinquency: Prevalence, causes, and interventions] (pp. 225-244). Houten: Bohn Stafleu Van Loghum.

*Dishion, T. J., Patterson, G. R., Stoolmiller, M., \& Skinner, M. L. (1991). Family, school, and behavioral antecedents to early adolescent involvement with antisocial peers. Developmental Psychology, 27(1), 172-180.

Drakeford, M. (1996). Parents of young people in trouble. The Howard Journal, 35(3), 242-255.

Dundes, L. (1994). Punishing parents to deter delinquency: A realistic remedy. American Journal of Police, 13(4), 113-133.

*Estevez, E., Musitu, G., \& Herrero, J. (2005). The influence of violent behavior and victimization at school on psychological distress: The role of parents and teachers. Adolescence, 40(157), 183-196.

*Farrington, D. P. (1989). Early predictors of adolescent aggression and adult violence. Violence and Victims, 4(2), 79-100.

*Farrington, D. P. (1990). Implications of criminal career research for the prevention of offending. Journal of Adolescence, 13(2), 93113.

*Farrington, D. P. (2002). Multiple risk factors for multiple problem violent boys. In R. R. Corrado, R. Roesch, S. D. Hart, \& J. K. Gierowski (Eds.), Multi problem violent youth: A foundation for comparative research on needs, interventions and outcomes (vol. Vol. 324, (pp. 23-34)). Amsterdam: IOS Press.

Farrington, D. P. (2005). Conclusions about developmental and lifecourse theories. In D. P. Farrington (Ed.), Integrated developmental and life course theories in offending(vol. 14). Piscataway, NJ: Transaction Publishers.

*Farrington, D. P., \& Hawkins, J. D. (1991). Predicting participation, early onset and later persistence in officially recorded offending. Criminal Behaviour and Mental Health, 1(1), 1-33.

Farrington, D. P., Jolliffe, D., Loeber, R., Stouthamer-Loeber, M., \& Kalb, L. M. (2001). The concentration of offenders in families, and family criminality in the prediction of boys' delinquency. Journal of Adolescence, 24(5), 579-596.

*Farrington, D. P., \& Loeber, R. (1999). Transatlantic replicability of risk factors in the development of delinquency. In P. Cohen, C. Slomkowski, \& L. N. Robins (Eds.), Historical and geographical 
influences on psychopathology (pp. 299-329). Mahwah, NJ: Erlbaum.

*Farrington, D. P., Loeber, R., \& Stouthamer-Loeber, M. (2003). How can the relationship between race and violence be explained. In D. F. Hawkins (Ed.), Violent crimes: Assessing race and ethnic differences (pp. 213-237). New York: Cambridge University Press.

*Farrington, D. P., Loeber, R., Yin, Y., \& Anderson, S. J. (2002). Are within-individual causes of delinquency the same as betweenindividual causes. Criminal Behaviour and Mental Health, 12(1), 53-68.

*Feldman, S. S., \& Weinberger, D. A. (1994). Self-restraint as a mediator of family influences on boys' delinquent behavior: A longitudinal study. Child Development, 65(1), 195-211.

*Finkenauer, C., Engels, R. C. M. E., \& Baumeister, R. F. (2005). Parenting behaviour and adolescent behavioural and emotional problems: The role of self-control. International Journal of Behavioral Development, 29(1), 58-69.

Fischer, D. G. (1983). Parental supervision and delinquency. Perceptual and Motor Skills, 56(2), 635-640.

*Flannery, D. J., Williams, L. L., \& Vazsonyi, A. T. (1999). Who are they with and what are they doing? Delinquent behavior, substance use, and early adolescents' after-school time. American Journal of Orthopsychiatry, 69(2), 247-253.

*Fletcher, A. C., Steinberg, L., \& Williams-Wheeler, M. (2004). Parental influences on adolescent problem behavior: Revisiting Stattin and Kerr. Child Development, 75(3), 781-796.

*Gainey, R. R., Catalano, R. F., Haggerty, K. P., \& Hoppe, M. J. (1997). Deviance among the children of heroin addicts in treatment: Impact of parents and peers. Deviant Behavior, 18 (2), 143-159.

Gendreau, P., Little, T., \& Goggin, C. (1996). A meta-analysis of the predictors of adult offender recidivism: What works!. Criminology, 34(4), 575-607.

*Gersao, E., \& Lisboa, M. (1994). The self-report delinquency study in Portugal. In J. Junger-Tas, G. J. Terlouw, \& M. W. Klein (Eds.), Delinquent behavior among young people in the Western world (pp. 212-237). Amsterdam: Kugler.

*Giever, D. M. (1996). An empirical assessment of the core elements of Gottfredson and Hirschi's General Theory of Crime. Dissertation Abstracts International, A: The Humanities and Social Sciences, 56(10), 4155-A (Doctoral dissertation, Indiana University of Pennsylvania, 1996).

*Glueck, E., \& Glueck, S. (1968). Delinquents and nondelinquents in perspective. Cambridge, Massachusetts: Harvard University Press.

*Glueck, S., \& Glueck, E. (1950). Unraveling juvenile delinquency. Cambridge: Harvard University Press.

Gottfredson, M. R., \& Hirschi, T. (1990). A general theory of crime. Palo Alto: Stanfort University Press.

Gove, W. R., \& Crutchfield, R. D. (1982). The family and juvenile delinquency. Sociological Quarterly, 23(3), 301-319.

*Graham, J., \& Bowling, B. (1995). Young people and crime (No. Home Office Research Study, vol.145). London: Research and Statistics Department, Home Office.

Granic, I. (2000). The self-organization of parent-child relations: Beyond bidirectional models. In M. D. Lewis, \& I. Granic (Eds.), Emotion, development, and self organization: Dynamic systems approaches to emotional development (pp. 267-297). New York: Cambridge University Press.

*Gray-Ray, P., \& Ray, M. C. (1990). Juvenile delinquency in the Black community. Youth and Society, 22(1), 67-84.

*Griffin, K. W., Botvin, G. J., Scheier, L. M., Diaz, T., \& Miller, N. L. (2000). Parenting practices as predictors of substance use, delinquency, and aggression among urban minority youth: Moderating effects of family structure and gender. Psychology of Addictive Behaviors, 14(2), 174-184.
*Hay, C. (2003). Family strain, gender, and delinquency. Sociological Perspectives, 46, 107-135.

*Hay, C., Fortson, E. N., Hollist, D. R., Altheimer, I., \& Schaible, L. M. (2006). The impact of community disadvantage on the relationship between the family and juvenile crime. Journal of Research in Crime and Delinquency, 43(4), 326-356.

*Haynie, D. L. (2003). Contexts of risk? Explaining the link between girls' pubertal development and their delinquency involvement. Social Forces, 82(1), 355-397.

*Heaven, P. C. L., Newbury, K., \& Mak, A. (2004). The impact of adolescent and parental characteristics on adolescent levels of delinquency and depression. Personality and Individual Differences, 36(1), 173-185.

*Heaven, P. C. L., \& Virgen, M. (2001). Personality, perceptions of family and peer influences, and males' self-reported delinquency. Personality and Individual Differences, 30(2), 321-331.

Hedges, L. V., \& Olkin, I. (1985). Statistical methods for metaanalysis. New York: Academic.

*Herman, M. R., Dornbusch, S. M., Herron, M. C., \& Herting, J. R. (1997). The influence of family regulation, connection, and psychological autonomy on six measures of adolescent functioning. Journal of Adolescent Research, 12(1), 34-67.

*Herrenkohl, T. I., Maguin, E., Hill, K. G., Hawkins, J., Abbott, R. D., $\&$ Catalano, R. F. (2000). Developmental risk factors for youth violence. Journal of Adolescent Health, 26(3), 176-186.

*Hetherington, E. M., Stouwie, R. J., \& Ridberg, E. H. (1971). Patterns of family interaction and child-rearing attitudes related to three dimensions of juvenile delinquency. Journal of Abnormal Psychology, 78(2), 160-176.

*Hill, G. D., \& Atkinson, M. P. (1988). Gender, familial control, and delinquency. Criminology: An Interdisciplinary Journal, 26(1), 127-147.

*Hirschi, T. (1969). Causes of delinquency. Berkeley: University of California Press.

Hirschi, T., \& Gottfredson, M. R. (2001). Control theory and the lifecourse perspective. In A. Piquero, \& P. Mazerolle (Eds.), Lifecourse criminology: Contemporary and classic readings (pp. 229-241). Toronto: Wadsworth.

*Hodgins, S., Kratzer, L., \& McNeil, T. F. (2001). Obstetric complications, parenting, and risk of criminal behavior. Archives of General Psychiatry, 58(8), 746-752.

Hoeve, M., Blokland, A., Dubas, J. S., Loeber, R., Gerris, J. R. M., \& Van der Laan, P. H. (2008). Trajectories of delinquency and parenting styles. Journal of Abnormal Child Psychology, 36(2), 223-235.

*Hoeve, M., Smeenk, W. H., Loeber, R., Stouthamer-Loeber, M., Van der Laan, P. H., Gerris, J. R. M., et al. (2007). Long term effects of parenting and family characteristics on delinquency of male young adults. European Journal of Criminology, 4(2), 116-194.

Holden, G. W. (1997). Parents and the dynamics of child rearing. Boulder: Westview Press.

Holden, G. W., \& Miller, P. C. (1999). Enduring and different: A meta-analysis of the similarity in parents' child rearing. Psychological Bulletin, 125(2), 223-254.

*Hooper, R. M. (1989). The etiological significance of morphology, arousal reduction and parent effectiveness to criminality. Dissertation Abstracts International, A: The Humanities and Social Sciences, 49(8), 2400-A (Doctoral dissertation, New York University, 1989)

Hubbard, D. J., \& Pratt, T. C. (2002). A meta-analysis of the predictors of delinquency among girls. Journal of Offender Rehabilitation, 34(3), 1-13.

*Jacobson, K. C., \& Crockett, L. J. (2000). Parental monitoring and adolescent adjustment: An ecological perspective. Journal of Research on Adolescence, 10(1), 65-97.

Jaffee, S. R., Moffitt, T. E., Caspi, A., \& Taylor, A. (2003). Life with (or without) father: The benefits of living with two biological 
parents depend on the father's antisocial behavior. Child Development, 74(1), 109-126.

*Jensen, G. F. (1972). Parents, peers, and delinquent action: A test of the differential association perspective. American Journal of Sociology, 78(3), 562-575.

*Johnson, J. G., Smailes, E., Cohen, P., Kasen, S., \& Brook, J. S. (2004). Anti-social parental behaviour, problematic parenting and aggressive offspring behaviour during adulthood. British Journal of Criminology, 44, 915-930.

*Johnson, R. E. (1987). Mother's versus father's role in causing delinquency. Adolescence, 22(86), 305-315.

*Jones, D. J., Forehand, R., \& Beach, S. R. H. (2000). Maternal and paternal parenting during adolescence: Forecasting early adult psychosocial adjustment. Adolescence, 35(139), 513-530.

*Jonsson, G. (1967). Delinquent boys, their parents and grandparents. Acta Psychiatrica Scandinavica, 43(Suppl. 195), 264.

Juang, L. P., \& Silbereisen, R. K. (1999). Supportive parenting and adolescent adjustment across time in former East and West Germany. Journal of Adolescence, 22(6), 719-736.

*Juras, J. L. (2004). Integrating models of risk and protection for the prevention of adolescent delinquency. Dissertation Abstracts International, 65(4 B), 2126 (UMI No. 3129497).

Kazdin, A. E. (2001). Bridging the enormous gaps of theory with therapy research and practice. Journal of Clinical Child Psychology, 30(1), 59-66.

*Kerr, M., \& Stattin, H. (2000). What parents know, how they know it, and several forms of adolescent adjustment: Further support for a reinterpretation of monitoring. Developmental Psychology, 36(3), 366-380.

Kerr, M., \& Stattin, H. (2003). Parenting of adolescents: Action or reaction? In A. C. Crouter, \& A. Booth (Eds.), Children's influence on family dynamics: The neglected side of family relationships (pp. 121-151). Mahwah, NJ: Erlbaum.

*Kerr, M., Stattin, H., \& Trost, K. (1999). To know you is to trust you: Parents' trust is rooted in child disclosure of information. Journal of Adolescence, 22(6), 737-752.

*Kolvin, I., Miller, F. J., Fleeting, M., \& Kolvin, P. A. (1988). Social and parenting factors affecting criminal-offence rates: Findings from the Newcastle Thousand Family Study (1947-1980). British Journal of Psychiatry Jan, 152, 80-90.

*Kosterman, R., Graham, J., Hawkins, J., Catalano, R. F., \& Herrenkohl, T. I. (2001). Childhood risk factors for persistence of violence in the transition to adulthood: A Social development perspective. Violence and Victims, 16, 355-370.

*Krohn, M., \& Massey, J. L. (1980). Social control and delinquent behavior: An examination of the elements of the social bonds. Sociological Quarterly, 21, 529-543.

*Krohn, M., Stern, S. B., Thornberry, T., \& Jang, S. J. (1992). The measurement of family process variables: An examination of adolescent and parent perception of family life and delinquent behavior. Journal of Quantitative Criminology, 8, 287-315.

*Kroupa, S. E. (1988). Perceived parental acceptance and female juvenile delinquency. Adolescence, 23(89), 171-185.

*Kruttschnitt, C., \& Dornfeld, M. (1991). Childhood victimization, race, and violent crime. Criminal Justice and Behavior, 18(4), 448-463.

*Kupanoff, K. M. (2002). Adolescent behavioral autonomy as a moderator between parenting practices and adolescent delinquency. Dissertation Abstracts International, 63(5 B), 2621 (UMI No. 3054634).

Laible, D. J., \& Carlo, G. (2004). The differential relations of maternal and paternal support and control to adolescent social competence, self-worth, and sympathy. Journal of Adolescent Research, 19(6), 759-782.

*Laird, R. D., Pettit, G. S., Bates, J. E., \& Dodge, K. A. (2003). Parents' monitoring-relevant knowledge and adolescents' de- linquent behavior: Evidence of correlated developmental changes and reciprocal influences. Child Development, 74(3), $752-768$.

Lanz, M., Scabini, E., Vermulst, A. A., \& Gerris, J. R. M. (2001). Congruence on child rearing in families with early adolescent and middle adolescent children. International Journal of Behavioral Development, 25(2), 133-139.

*Larzelere, R. E., \& Patterson, G. (1990). Parental management: Mediator of the effect of socioeconomic status on early delinquency. Criminology, 28, 301-323.

*Lavoie, F., Hebert, M., Tremblay, R. E., Vitaro, F., Vezina, L., \& McDuff, P. (2002). History of family dysfunction and perpetration of dating violence by adolescent boys; A longitudinal study. Journal of Adolescent Health, 30(5), 375-383.

*LeBlanc, M., McDuff, P., \& Kaspy, N. (1998). Family and early adolescent delinquency: A comprehensive sequential family control mModel. Early Child Development and Care, 142, 6391.

*Lefkowitz, M. M., Eron, L. D., Walder, L. O., \& Huesmann, L. R. (1977). Growing up to be violent: A longitudinal study of the development of aggression. New York: Pergamon.

*Lempers, J. D., Clark Lempers, D., \& Simons, R. L. (1989). Economic hardship, parenting, and distress in adolescence. Child Development, 60(1), 25-39.

Lipsey, M. W., \& Derzon, J. H. (1998). Predictors of violent of serious delinquency in adolescence and early adulthood. In R. Loeber, \& D. P. Farrington (Eds.), Serious and violent juvenile offenders: Risk factors and successful interventions (pp. 86-105). Thousand Oaks, CA: Sage.

Lipsey, M. W., \& Wilson, D. B. (2001). Practical meta-analysis. Thousand Oaks, CA: Sage.

Loeber, R. (1996). Developmental continuity, change, and pathways in male juvenile problem behaviors and delinquency. In J. D. Hawkins (Ed.), Delinquency and crime: Current theories (pp. 127). New York: Cambridge University Press.

Loeber, R., \& Dishion, T. J. (1983). Early predictors of male delinquency: A review. Psychological Bulletin, 94(1), 68-99.

Loeber, R., Farrington, D. P., Stouthamer-Loeber, M., \& White, H. R. (2008). Violence and serious theft: Development and prediction from childhood to adulthood. Mahwah, NJ: Erlbaum.

Loeber, R., \& Stouthamer-Loeber, M. (1986). Family factors as correlates and predictors of juvenile conduct problems and delinquency. In M. H. Tonry, \& N. Morris (Eds.), Crime and justice: An annual review of research (vol. Vol. 7, (pp. 29-149)). Chicago: University of Chicago Press.

*Loukas, A., Suizzo, M. A., \& Prelow, H. M. (2007). Examining resource and protective factors in the adjustment of Latino youth in low income families: What role does maternal acculturation play? Journal of Youth and Adolescence, 36(4), 489-501.

Lundahl, B. W., Tollefson, D., Risser, H., \& Lovejoy, M. C. (2008). A meta-analysis of father involvement in parent training. Research on Social Work Practice, 18(2), 97-106.

*Luo, Q. (2000). Parenting and friend affiliation in adolescent development: A cross-cultural comparison. Dissertation Abstracts International, 61, 1673 (Doctoral dissertation, Wayne State University, 2000).

Maccoby, E. E., \& Martin, J. A. (1983). Socialization in the context of the family: Parent-child interaction. In P. H. Mussen (Ed.), Handbook of child psychology: Socialization, personality and social development (vol. IV, (pp. 1-101)). New York: Wiley.

*Macie, K. M. (2003). The influence of co-parenting and parental marital status on the long-term adjustment of young adults. Virginia Commonwealth U., USA.

*Madoff, J. M. (1959). The attitudes of mothers of juvenile delinquents toward child rearing. ournal of Consulting Psychology, 23, 518-520. 
*Mak, A. S. (1994). Parental neglect and overprotection as risk factors in delinquency. Australian Journal of Psychology, 46(2), 107-111.

*Mason, C. A. (1996). Neither too sweet nor too sour: Problem peers, maternal control, and problem behavior in African American adolescents. Child Development, 67(5), 2115-2130.

McCart, M. R., Priester, P. E., Davies, W., \& Azen, R. (2006). Differential effectiveness of behavioral parent-training and cognitive-behavioral therapy for antisocial youth: A metaanalysis. Journal of Abnormal Child Psychology, 34(4), 527543.

McCartney, K., \& Rosenthal, R. (2000). Effect size, practical importance, and social policy for children. Child Development, $71(1), 173-180$.

*McCord, J. (1990). Long-term perspectives on parental absence. In L. N. Robins, \& M. Rutter (Eds.), Straight and devious pathways from childhood to adulthood (pp. 116-134). New York: Cambridge University Press.

*McCord, J. (1991a). The cycle of crime and socialization practices. Journal of Criminal Law and Criminology, 82, 211-228.

*McCord, J. (1991b). Family relationships, juvenile delinquency and adult criminality. Criminology, 29, 397-417.

* McCord, J. (1996). Family as crucible for violence: Comment on Gorman-Smith et al. (1996). Journal of Family Psychology, 10 (2), 147-152.

*McCord, W., McCord, J., \& Zola, I. K. (1959). Origins of crime: A new evaluation of the Cambridge-Somerville Youth Study. New York: Cambridge University Press.

*Medinnus, G. R. (1965). Delinquents' perceptions of their parents. Journal of Consulting Psychology, 29(6), 592-593.

Moffitt, T. E. (1993). Adolescence-limited and life-course-persistent antisocial behavior: A developmental taxonomy. Psychological Review, 100(4), 674-701.

Moffitt, T. E. (2006). Life-course persistent versus adolescencelimited antisocial behavior. In D. Cicchetti, \& D. J. Cohen (Eds.), Developmental Psychopathology: Risk, disorder, and adaptation (vol. 3, pp. 570-598, 2nd ed.). New York: Wiley.

Moffitt, T. E., \& Caspi, A. (2001). Childhood predictors differentiate life-course-persistent and adolescence-limited antisocial pathways among males and females. Development and Psychopathology, 13(2), 355-375.

Moffitt, T. E., Caspi, A., Rutter, M., \& Silva, P. A. (2001). Sex differences in antisocial behaviour: Conduct disorder, delinquency, and violence in the Dunedin Longitudinal Study. New York: Cambridge University Press.

*Mojallali, S. (1972). Adolescents' perception of parental behavior toward them and its relationship with sex, delinquency, and security. Dissertation Abstracts International, 33, 903 (Doctoral dissertation, North Texas State University, 1972).

*Mounts, N. S. (2001). Young adolescents' perceptions of parental management of peer relationships. Journal of Early Adolescence, 21(1), 92-122.

Mulford, C. F., \& Redding, R. E. (2008). Training the parents of juvenile offenders: State of the art and recommendations for service delivery. Journal of Child and Family Studies, 17(5), 629-648.

Mullen, B. (1989). Advanced BASIC meta-analysis. Hillsdale, NJ: Erlbaum.

Noller, P., \& Callan, V. J. (1988). Understanding parent-adolescent interactions: Perceptions of family members and outsiders. Developmental Psychology, 24(5), 707-714.

*Nye, F. I. (1958). Family relationships and delinquent behavior. New York: Wiley.

*O'Connor, B. P., \& Dvorak, T. (2001). Conditional associations between parental behavior and adolescent problems: A search for personality-environment interactions. Journal of Research in Personality, 35(1), 1-26.
O'Connor, T. G. (2002). Annotation: The 'effects' of parenting reconsidered: Findings, challenges, and applications. Journal of Child Psychology and Psychiatry, 43(5), 555-572.

*Paschall, M. J., Ringwalt, C. L., \& Flewelling, R. L. (2003). Effects of parenting, father absence, and affiliation with delinquent peers on delinquent behavior among African-American male adolescents. Adolescence, 38(149), 15-34.

Patterson, G. R. (1982). Coercive family process. Eugene, OR: Castalia.

*Patterson, G. R., \& Dishion, T. J. (1985). Contributions of families and peers to delinquency. Criminology, 23(1), 63-79.

Patterson, G. R., \& Yoerger, K. (1993). Developmental models for delinquent behavior. In S. Hodgins (Ed.), Mental disorder and crime (pp. 140-172). Thousand Oaks, CA: Sage.

*Patterson, G. R., \& Yoerger, K. (1995). Two different models for adolescent physical trauma and for early arrest. Criminal Behaviour and Mental Health, 5(4), 411-423.

Patterson, G. R., \& Yoerger, K. (2002). A developmental model for early- and late-onset delinquency. In J. B. Reid, G. R. Patterson, \& J. Snyder (Eds.), Antisocial behavior in children and adolescents: A developmental analysis and model for intervention (pp. 147-172). Washington, DC: American Psychological Association.

*Pedersen, W. (2000). Crime and punishment in Norwegian midadolescents: A normal population study. Journal of Scandinavian Studies in Criminology and Crime Prevention, 1(1), 87-104.

*Peiser, N. C., \& Heaven, P. C. L. (1996). Family influences on selfreported delinquency among high school students. Journal of Adolescence, 19(6), 557-568.

*Peterson, D. (2002). "Don't forget the women": A multi-level analysis of individual and contextual effects on girls' and boys' delinquency. Dissertation Abstracts International, A: The Humanities and Social Sciences, 63(3), 1140-A (Doctoral dissertation, University of Nebraska, 2002).

*Pettit, G. S., Laird, R. D., Dodge, K. A., Bates, J. E., \& Criss, M. M. (2001). Antecedents and behavior-problem outcomes of parental monitoring and psychological control in early adolescence. Child Development, 72(2), 583-559.

*Piquero, A. R., Brezina, T., \& Turner, M. G. (2005). Testing Moffitt's account of delinquency abstention. Journal of Research in Crime and Delinquency, 42(1), 27-54.

*Rankin, J. H., \& Kern, R. (1994). Parental attachments and delinquency. Criminology, 32(4), 495-515.

*Rasmussen, K. S. (1995). Parental control and adolescent aggression, delinquency, self-derogation, and suicidal ideation. Brigham Young U, USA.

*Reitz, E., Prinzie, P., Dekovic, M., \& Buist, K. L. (2007). The role of peer contacts in the relationship between parental knowledge and adolescents' externalizing behaviors: A latent growth curve modeling approach. Journal of Youth and Adolescence, 36(5), 623-634.

*Riley, D., \& Shaw, J. M. (1985). Parental supervision and delinquency. In Home Office Research Study (vol. 83). London: Her Majesty's Stationery Office.

*Roche, K. M., Ensminger, M. E., \& Cherlin, A. J. (2007). Variations in parenting and adolescent outcomes among African American and Latino families living in low-income, urban areas. Journal of Family Issues, 28(7), 882-909.

Rohner, R. P. (2004). The parental "acceptance-rejection syndrome": Universal correlates of perceived rejection. American Psychologist, 59(8), 830-840.

Rollins, B. C., \& Thomas, D. L. (1979). Parental support, power and control techniques in the socialization of children. In W. R. Bur, R. Hill, F. I. Nye, \& I. L. Reiss (Eds.), Contemporary theories about the family (vol. I, (pp. 317-364)). London: Free Press.

Rosenthal, R. (1979). The "file drawer problem" and tolerance for null results. Psychological Bulletin, 86(3), 638-641. 
Rosenthal, R. (1991). Meta-analytic procedures for social research (vol. 86). Newbury Park, CA: Sage.

Rosenthal, R. (1995). Writing meta-analytic reviews. Psychological Bulletin, 118(2), 183-192.

Rothbaum, F., \& Weisz, J. R. (1994). Parental caregiving and child externalizing behavior in nonclinical samples: A meta-analysis. Psychological Bulletin, 116(1), 55-74.

*Samaniego, R. Y., \& Gonzales, N. A. (1999). Multiple mediators of the effects of acculturation status on delinquency for Mexican American adolescents. American Journal of Community Psychology, 27(2), 189-210.

*Sampson, R. J., \& Laub, J. H. (1993). Crime in the making: Pathways and turning points through life. Cambridge (MA): Harvard University Press.

*Sampson, R. J., \& Laub, J. H. (1994). Urban poverty and the family context of delinquency: A new look at structure and process in a classic study. Child Development, 65(2), 523-540.

Sampson, R. J., \& Laub, J. H. (2001a). A life-course theory of cumulative disadvantage and the stability of delinquency. In A. Piquero, \& P. Mazerolle (Eds.), Life-course criminology: Contemporary and classic readings (pp. 146-169). Toronto: Wadsworth.

Sampson, R. J., \& Laub, J. H. (2001b). Understanding variablility in lives through time: Contributions of life-course criminology. In A. Piquero, \& P. Mazerolle (Eds.), Life-course criminology: Contemporary and classic readings (pp. 242-258). Toronto: Wadsworth.

Sampson, R. J., \& Laub, J. H. (2005). A general age-graded theory of crime: Lessons learned and the future of life-course criminology. In D. P. Farrington (Ed.), Integrated developmental and life course theories of offending(vol. 14). Piscataway, NJ: Transaction Publishers.

*Scholte, E. M. (1999). Factors predicting continued violence into young adulthood. Journal of Adolescence, 22(1), 3-20.

*Seydlitz, R. (1993). Complexity in the relationships among direct and indirect parental controls and delinquency. Youth and Society, 24(3), 243-275.

*Shaw, J. M., \& Scott, W. A. (1991). Influence of parent discipline style on delinquent behaviour: The mediating role of control orientation. Australian Journal of Psychology, 43(2), 61-67.

*Sheline, J. L., Skipper, B. J., \& Broadhead, W. E. (1994). Risk factors for violent behavior in elementary school boys: Have you hugged your child today. American Journal of Public Health, 84 (4), 661-663.

*Simons, R. L. (1994). Harsh corporal punishment versus quality of parental involvement as an explanation of adolescent maladjustment. Journal of Marriage and the Family, 56(3), 591-607.

*Simons, R. L., Johnson, C., Conger, R. D., et al. (1998). A test of latent trait versus life-course perspectives on the stability of adolescent antisocial behavior. Criminology, 36(2), 217-243.

*Simons, R. L., Lin, K. H., \& Gordon, L. C. (1998). Socialization in the family of origin and male dating violence: A prospective study. Journal of Marriage and the Family, 60(2), 467-478.

*Simons, R. L., Robertson, J. F., \& Downs, W. R. (1989). The nature of the association between parental rejection and delinquent behavior. Journal of Youth and Adolescence, 18(3), 297-310.

*Simons, R. L., Simons, L. G., Burt, C. H., Brody, G. H., \& Cutrona, C. (2005). Collective efficacy, authoritative parenting and delinquency: A longitudinal test of a model integrating community- and family-level processes. Criminology: An Interdisciplinary Journal, 43(4), 989-1029.

*Simons, R. L., Whitbeck, L. B., Conger, R. D., \& Conger, K. J. (1991). Parenting factors, social skills, and value commitments as precursors to school failure, involvement with deviant peers, and delinquent behavior. Journal of Youth and Adolescence, 20(6), 645-664.
*Singer, M. I., Miller, D. B., Guo, S., et al. (1999). Contributors to violent behavior among elementary and middle school children. Pediatrics, 104(4), 878-884.

*Skinner, K. B. (2000). Associations between parenting, acculturation, and adolescent functioning among Chinese families in North America. Dissertation Abstracts International, A: The Humanities and Social Sciences, 61(2), 784-A (Doctoral dissertation, Brigham Young University, 2000).

*Smith, D. J., \& McVie, S. (2003). Theory and method in the Edinburgh Study of Youth Transitions and Crime. British Journal of Criminology, 43(1), 169-195.

*Stattin, H., \& Kerr, M. (2000). Parental monitoring: A reinterpretation. Child Development, 71(4), 1072-1085.

Steinberg, L. (2001). We know some things: Parent-adolescent relationships in retrospect and prospect. Journal of Research on Adolescence, 11(1), 1-19.

*Steinberg, L., Blatt Eisengart, I., \& Cauffman, E. (2006). Patterns of competence and adjustment among adolescents from authoritative, authoritarian, indulgent, and neglectful homes: A replication in a sample of serious juvenile offenders. Journal of Research on Adolescence, 16(1), 47-58.

Steinberg, L., Lamborn, S. D., Darling, N., Mounts, N. S., \& Dornbusch, S. M. (1994). Over-time changes in adjustment and competence among adolescents from authoritative, authoritarian, indulgent, and neglectful families. Child Development, 65(3), 754-770.

*Steinberg, L., Mounts, N. S., Lamborn, S. D., \& Dornbusch, S. M. (1991). Authoritative parenting and adolescent adjustment across varied ecological niches. Journal of Research on Adolescence, 1 (1), 19-36.

*Stewart, E. A., Simons, R. L., Conger, R. D., \& Scaramella, L. V. (2002). Beyond the interactional relationship between delinquency and parenting practices: The contribution of legal sanctions. Journal of Research in Crime and Delinquency, 39(1), 36-59.

*Stouthamer-Loeber, M., Loeber, R., Wei, E. H., Farrington, D. P., \& Wikström, P.-O. H. (2002). Risk and promotive effects in the explanation of persistent serious delinquency in boys. Journal of Consulting and Clinical Psychology, 70(1), 111-123.

*Stuewig, J. (2001). Factors related to the desistance of crime in a longitudinal sample. Dissertation Abstracts International, 61, 4452 (Doctoral dissertation, University of Arizona, 2001).

Tabachnick, B. G., \& Fidell, L. S. (1989). Using multivariate statistics. New York: Harper Collins.

*Tavecchio, L. W. C., Stams, G. J. J. M., Brugman, D., \& ThomeerBouwens, M. A. E. (1999). Moral judgement and delinquency in homeless youth. Journal of Moral Education, 28(1), 63-79.

Ten Haaf, P. G. J. (1993). Opvoedingsdimensies: Convergente en discriminante validiteit [Child-rearing dimensions: Convergent and discriminant validity]. Katholieke Universiteit Nijmegen, Nijmegen.

Ten Haaf, P. G. J., Janssens, J. M. A. M., \& Gerris, J. R. M. (1994). Child-rearing measures: Convergent and discriminant validity. European Journal of Psychological Assessment, 10(2), 111-128.

*Terlouw, G.-J., \& Bruinsma, G. J. N. (1994). Self-reported delinquency in the Netherlands. In J. Junger-Tas, G.-J. Terlouw, $\&$ M. W. Klein (Eds.), Delinquent behavior among young people in the Western world. Amsterdam: Kugler.

*Tremblay, R. E. (1995). Kindergarten behavioral patterns, parental practices, and early adolescent antisocial behavior. In J. McCord (Ed.), Coercion and Punishment in Longterm Perspectives. New York, NY: Cambridge University Press.

*Unnever, J. D., Cullen, F. T., \& Agnew, R. (2006). Why is "bad" parenting criminogenic?: Implications from rival theories. Youth Violence and Juvenile Justice, 4(1), 3-33.

*Van Voorhis, P., Cullen, F. T., Mathers, R. A., \& Garner, C. C. (1988). The impact of family structure and quality on delinquency: A 
comparative assessment of structural and funcyional factors. Criminology, 26, 235-261.

*Vazsonyi, A. T. (1996). Family socialization and delinquency in the United States and Switzerland. European Journal on Criminal Policy and Research, 4(2), 81-100.

*Vazsonyi, A. T., \& Flannery, D. J. (1997). Early adolescent delinquent behaviors: Associations with family and school domains. Journal of Early Adolescence, 17(3), 271-293.

*Vega, W. A., Gil, A. G., Warheit, G. J., Zimmerman, R. S., et al. (1993). Acculturation and delinquent behavior among Cuban American adolescents: Toward an empirical model. American Journal of Community Psychology, 21(1), 113-125.

Videon, T. M. (2005). Parent-child relations and children's psychological well-being: Do dads matter. Journal of Family Issues, 26(1), 55-78.

*Vissing, Y. M. (1991). Verbal aggression by parents and psychosocial problems of children. Child Abuse and Neglect: The International Journal, 15(3), 223-238.

*Vitaro, F., Brendgen, M., \& Tremblay, R. E. (2000). Influence of deviant friends on delinquency: Searching for moderator variables. Journal of Abnormal Child Psychology, 28(4), 313325.

*Voss, K. (2001). Understanding adolescent antisocial behaviour from attachment theory and coercion theory perspectives. Dissertation Abstracts International, 61(12 B), 6725 (UMI No. 54386).

*Walker-Barnes, C. J., \& Mason, C. A. (2001). Ethnic differences in the effect of parenting on gang involvement and gang delinquency: A longitudinal, hierarchical linear modeling perspective. Child Development, 72(6), 1814-1831.

*Warr, M. (1993). Parents, peers, and delinquency. Social Forces, 72 (1), 247-264.

*Weintraub, K. J., \& Gold, M. (1991). Monitoring and delinquency. Criminal Behaviour and Mental Health, 1(3), 268-281.

*Wells, L. E., \& Rankin, J. H. (1988). Direct parental controls and delinquency. Criminology, 26, 263-285.

*Werner, N. E., \& Silbereisen, R. K. (2003). Family relationship quality and contact with deviant peers as predictors of adolescent problem behaviors: The moderating role of gender. Journal of Adolescent Research, 8(5), 454-480.

*West, D. J., \& Farrington, D. P. (1973). Who becomes delinquent? Second report of the Cambridge Study in Delinquent Development. London: Heinemann Educational.

*West, D. J., \& Farrington, D. P. (1977). The delinquent way of life. London: Heinemann.

*Williams, A. J. (2004). Risk factors for selected health-related behaviors among American Indian Adolescents. Dissertation Abstracts International, 65(3 B), 1602 (UMI No. 3127762).

Williams, S. K., \& Kelly, F. D. (2005). Relationships among involvement, attachment, and behavioral problems in adolescence: Examining father's influence. Journal of Early Adolescence, 25(2), 168-196.

*Wilson, H. (1980). Parents can cut the crime rate. New Society, 54 (942), 456-458.

*Wilson, H. (1987). Parental supervision re-examination. British Journal of Criminology, 27(3), 275-301.

*Windham, A. M. (2003). Pathways to problem drug use: The role of early maternal nurturing. Dissertation Abstracts International, 63 (10 B), 4632 (UMI No. 3068230).

*Wissink, I. B., Dekovic, M., \& Meijer, A. M. (2006). Parenting behavior, quality of the parent-adolescent relationship, and adolescent functioning in four ethnic groups. Journal of Early Adolescence, 26(2), 133-159.

*Wright, J. P., \& Cullen, F. T. (2001). Parental efficacy and delinquent behavior: Do control and support matter. Criminology, 39(3), 677705.

Wright, J. P., Cullen, F. T., \& Wooldredge, J. D. (2000). Parental support and juvenile delinquency. Contemporary Perspectives in Family Research, 2, 139-161.

References marked with an asterisk indicate studies included in the meta-analysis. 